Review

\title{
Neuroinflammation in Cerebral Ischemia and Ischemia/Reperfusion Injuries: From Pathophysiology to Therapeutic Strategies
}

\author{
Anamaria Jurcau 1,2,*(D) and Aurel Simion 1,3 \\ 1 Department of Psycho-Neurosciences and Rehabilitation, Faculty of Medicine and Pharmacy, \\ University of Oradea, 410087 Oradea, Romania; aurel.simion1962@gmail.com \\ 2 Neurology Ward, Clinical Municipal Hospital “dr. G. Curteanu” Oradea, 410154 Oradea, Romania \\ 3 Neurorehabilitation Ward, Clinical Municipal Hospital "dr. G. Curteanu" Oradea, 410154 Oradea, Romania \\ * Correspondence: anamaria.jurcau@gmail.com
}

check for updates

Citation: Jurcau, A.; Simion, A. Neuroinflammation in Cerebral Ischemia and Ischemia/Reperfusion Injuries: From Pathophysiology to Therapeutic Strategies. Int. J. Mol. Sci. 2022, 23, 14. https://doi.org/ 10.3390/ijms23010014

Academic Editor: Kurt A. Jellinger

Received: 5 December 2021

Accepted: 18 December 2021

Published: 21 December 2021

Publisher's Note: MDPI stays neutral with regard to jurisdictional claims in published maps and institutional affiliations.

Copyright: (C) 2021 by the authors. Licensee MDPI, Basel, Switzerland. This article is an open access article distributed under the terms and conditions of the Creative Commons Attribution (CC BY) license (https:// creativecommons.org/licenses/by/ $4.0 /)$.

\begin{abstract}
Its increasing incidence has led stroke to be the second leading cause of death worldwide. Despite significant advances in recanalization strategies, patients are still at risk for ischemia/reperfusion injuries in this pathophysiology, in which neuroinflammation is significantly involved. Research has shown that in the acute phase, neuroinflammatory cascades lead to apoptosis, disruption of the blood-brain barrier, cerebral edema, and hemorrhagic transformation, while in later stages, these pathways support tissue repair and functional recovery. The present review discusses the various cell types and the mechanisms through which neuroinflammation contributes to parenchymal injury and tissue repair, as well as therapeutic attempts made in vitro, in animal experiments, and in clinical trials which target neuroinflammation, highlighting future therapeutic perspectives.
\end{abstract}

Keywords: ischemic stroke; neuroinflammation; microglia; astrocytes; chemokines; cytokines; stem cells

\section{Introduction}

Stroke is the second leading cause of death and a major cause of disability worldwide [1], with an increasing incidence [2] due to demographic changes and the increasing prevalence of diabetes mellitus [3] and obesity [4]. The treatment of ischemic stroke relies increasingly on recanalization strategies, with continuously expanding therapeutic time windows [5-8]. Unfortunately, reestablishing blood flow in a tissue previously subject to ischemia boosts oxidative stress [9] and leads to the increased release of pro-inflammatory cytokines [10], which trigger a series of pathological cascades which will directly or indirectly cause apoptosis, disruption of the blood-brain barrier (BBB), cerebral edema, and hemorrhagic transformation. Research has shown that neuroinflammatory mechanisms, intimately linked to oxidative stress, significantly contribute to neuronal injury in the acute phase of cerebral ischemia [11], ultimately increasing the magnitude of cerebral damage and neurological deficit [12,13] through ischemia/reperfusion (I/R) injuries. However, in later stages of cerebral ischemia, neuroinflammatory pathways have beneficial effects on tissue repair and functional recovery [14]. As such, unraveling these complex mechanisms and modulating them therapeutically could significantly improve our treatment strategies in ischemic stroke and the quality of life of stroke survivors.

The present paper provides an overview of the involvement of various cell types and pathways in neuroinflammation following acute ischemic stroke and a narrative review of preclinical and clinical studies performed so far (or that are underway) acting on neuroinflammatory mechanisms in an attempt to improve stroke outcome, highlighting promising future perspectives. 


\section{Inflammation in Ischemia/Reperfusion Injuries}

The brain is more difficult to access by immune cells from the periphery due to the presence of the BBB [15], which has a layer of endothelial cells interconnected by tight junctions placed on a basal membrane, which embeds a high number of pericytes [16], and ensheathed by astroglial endfeet on the abluminal aspect [17]. However, inflammation, initiated by stagnant blood flow and continued through the activation of intravascular leucocytes and the release of pro-inflammatory mediators from the endothelium and parenchymal cells, is able to substantially potentiate tissue injury [18].

It is, nonetheless, important to understand that the neuroinflammatory pathways discussed in the following sections are not merely damaging pathways but also include mechanisms which significantly contribute to reparative processes and enhance recovery after the ischemic insult [14,19]. In fact, research has shown that after acute ischemic stroke, the inflammatory process evolves in three stages [20]: (1) an acute phase in the first hours after stroke onset, during which microglia/macrophages clear the necrotized cells and a first entry of leukocytes, mainly neutrophils, has been described; (2) a subacute phase during the first days after the ischemic insult, associated with a resolution of the inflammatory process; and (3) a late stage, in which the inflammatory cells contribute to astrocytic and microglial reparatory processes. Table 1 summarizes the pathophysiology of cerebral ischemia and reperfusion injuries.

Table 1. Pathophysiology of cerebral ischemia and reperfusion injuries.

\section{Time Course}

Acute phase (minutes-hours)

\section{Pathophysiological Mechanisms}

Reduced cerebral blood flow with diminished oxygen and glucose delivery Anaerobic metabolism and lactic acidosis

Failure of ATPase, cellular depolarization, increased intracellular ion influx Release of neuromediators (excitotoxicity)

Increased expression of stress signaling genes
Increased production of ROS

Apoptosis

Expression of adhesion molecules

Subacute phase (hours-days)
Microglial activation and leukocyte infiltration of the brain

Release of pro-inflammatory mediators

Increased activity of proteolytic enzymes and damage of BBB and endothelium

Release of trophic factors (BDNF, IGF, GDNF)

Neurogenesis, angiogenesis, synaptogenesis

Activation of stem cells

ATPase-adenosine triphosphatase; ROS-reactive oxygen species; BBB-blood-brain barrier; BDNF-brainderived neurotrophic factor; IGF-insulin-like growth factor; GDNF-glial-derived neurotrophic factor.

\subsection{Intravascular Initiation of the Inflammatory Cascade}

The inflammatory cascade is activated immediately after vessel occlusion by the modified shear stress on the endothelium and altered blood rheology of stagnant blood flow [21]. P-selectin, stored in Weibel-Palade bodies in endothelial cells and in $\alpha$-granules in platelets, appears within minutes on the cell surface and, by interacting with P-selectin glycoprotein ligand-1 (PSGL-1) expressed on leucocytes, slows down circulating leucocytes and attracts them to the endothelial surface [18]. Platelet P-selectin also contributes to vascular clogging by binding to leucocytes and facilitating the formation of clusters of leucocytes [21], followed by the activation of coagulation. Inhibition of P-selectin-dependent interaction blocked fibrin deposition in a primate model of thrombosis [22].

Activation of the coagulation cascade leads to thrombin generation, which attracts additional monocytes and neutrophils, and induces the expression of adhesion molecules on endothelial cells through the activation of nuclear factor $\mathrm{\kappa B}$ (NF- $\mathrm{kB}$ ) [23]. Thus, intravascular inflammation is the initial step in BBB breakdown and leucocyte infiltration of the ischemic cerebral tissue. 
The acute oxygen and glucose deprivation also increases the production of reactive oxygen species (ROS) by cytosolic enzymes and mainly by mitochondria [9], with increased oxidative stress which self-propagates and induces the expression of genes encoding subunits of the $\alpha$-amino-3-hydroxy-5-methyl-4-isoxazole-propionic acid (AMPA) and kainite glutamate receptors. The consequence of this upregulated gene expression is excitotoxicity, with increases in intracellular calcium concentrations in neurons and to a lesser extent in astrocytes, leading to mitochondrial dysfunction and the initiation of apoptosis [24]. ROS also increase the expression of genes encoding pro-inflammatory factors, such as interleukin (IL) $1 \beta$, IL-10, and tumor necrosis factor- $\alpha$ [25], and downregulates the expression of protective genes encoding for subunits of phosphoinositide 3-kinase (PI3K), protein kinase B (Akt), protein kinase C, and calcium/calmodulin-dependent protein kinase II (CAMKII) [25]. Reperfusion, through increasing the oxygen supply, potentiates oxidative stress and its deleterious effects [26]. As such, antioxidants given early after stroke onset could not only increase cell survival but also dampen the inflammatory response elicited by acute ischemia [27].

\subsection{Parenchymal Inflammation in Cerebral I/R Injuries}

\subsubsection{Microglia in Neuroinflammation after Acute Ischemic Stroke}

The resident immune cells of the brain, representing $5-20 \%$ of the glial population, are microglia [28]. They are derived from myeloid progenitors from the yolk sac which seed the cerebral parenchyma during embryonic development [29]. Subsequently, microglia behave similarly to peripheral macrophages despite the latter originating from hematopoietic stem cells [30].

In the resting state, microglial cells have a small cell soma and numerous processes in constant motion which monitor the microenvironment of the CNS [31,32]. The expression of a series of receptors by microglia, such as CD200 receptors, colony-stimulating factor 1 receptors, receptors for chemokines (CX3CL1), neurotrophins, and neurotransmitters [33,34], enable neurons and astrocytes to maintain microglia in a relatively quiescent state $[35,36]$.

By expressing Toll-like receptors (TLRs), nucleotide-binding oligomerization domain (NOD)-like receptors (NLRs), and retinoic acid-inducible gene-1 (RIG-1)-like receptors (RLRs), microglia recognize pathogen-associated molecular patterns (PAMPs) and danger-associated molecular patterns (DAMPs), followed by induction of the nuclear factor-kappa B (NF-kB) and Toll/interleukin-1 receptor (TIR)-domain-containing adapterinducing interferon- $\beta$ (TRIF)-induced interferon regulatory factor-3 (IRF3) pathways [37,38].

Upon activation by endogenous stimuli generated following injury or infection, microglia retract their processes and take on an amoeboid shape [39,40]. After cerebral ischemia, damaged neurons from the ischemic core release neuromediators, DAMPs, highmobility group box-1 (HMGB1) protein, and reactive oxygen species (ROS), which activate microglia [41] and the NF-кB pathway. A similar, although more chronic, microglial activation occurs in neurodegenerative diseases as well [42]. Glutamate released by oxygenand glucose-deprived neurons stimulates the microglial metabotropic glutamate receptor II (mGluRII), leading to the release of TNF- $\alpha$ and activation through the NF- $\kappa$ B pathway [43]. The inhibitory I $\kappa \mathrm{B}$ protein, bound to NF- $\kappa \mathrm{B}$ in the cytoplasm, is phosphorylated and degraded by I $\kappa \mathrm{B}$ kinases, allowing the nuclear translocation of $\mathrm{NF}-\kappa \mathrm{B}$, where it promotes the transcription of pro-inflammatory cytokine genes [44,45]. Damaged neurons also release their fractalkine (CX3CL1) ligand, recognized by the microglial CX3CL1 receptor [46].

Once activated, microglia adopt different phenotypes: microglia with enlarged cell bodies with short ramifications and amoeboid cell structures with rare ramifications have been described in the peri-infarct regions in the post-acute phase, while round-shaped microglia, characterizing highly activated cells, have been found near the ischemic core [47]. Aside from the morphological changes, microglia also exhibit different gene expression patterns with distinct functions. Classically, the M1 phenotype is pro-inflammatory while the M2 phenotype has anti-inflammatory actions [48], with M2a phenotypes being involved in reparative and regenerative processes, $\mathrm{M} 2 \mathrm{~b}$ phenotypes displaying immunoregulatory 
properties, and M2c microglia clearing cellular debris [49]. M2a activation is induced by IL-4 and IL-13 [50,51]. M2b polarization has been observed with the triggering of TLRs and $\mathrm{Fc} \gamma$ receptors $(\mathrm{Fc} \gamma \mathrm{R}$-receptors for the Fc part of $\mathrm{IgG})$, while M2c polarization has been described in response to anti-inflammatory factors such as IL-10, transforming growth factor- $\beta$ (TGF- $\beta$ ), and glucocorticoids $[40,52]$. Chemokines, such as CCL2 and CXCL4, can also induce M2 polarization [53,54]. The various microglial phenotypes can be identified through their surface markers as well. M1 phenotypes express CD11b, CD45, CD68, CD16, CD32, Fc $\gamma$ R, and iNOS (inducible nitric oxide synthase) [55], while M2 phenotypes express CD206 (mannose receptor), arginase-1, and Ym1 (chitinase-like-3, Chi313), which prevent the degradation of extracellular matrix components [56].

Once activated and polarized towards an M1 phenotype, microglia release tumor necrosis factor-alpha (TNF- $\alpha$ ), inflammatory interleukins such as IL-1 $\beta$, IL-6, other inflammatory cytokines, and reactive oxidative species (ROS) into the circulation $[57,58]$. The cytokines and chemokines produced by microglia can recruit leukocytes to the injured parenchyma [59], which will release proteases and oxygen radicals, thereby potentiating tissue destruction [43].

M2-polarized microglia, by producing anti-inflammatory factors (IL-4, IL-10, IL-13, or TGF- $\beta$ ), contribute to the resolution of inflammation [60] and have important roles in tissue remodeling and repair as well as angiogenesis $[61,62]$ by producing insulin-like growth factor-1 (IGF1), which suppresses apoptosis and increases proliferation and differentiation of neural precursor cells (NPCs) [56], brain-derived neurotrophic factor (BDNF), and neuronal growth factor (NGF) [63].

Being highly plastic cells, microglia can shift between different phenotypes $[64,65]$, as demonstrated in an experimental model of autoimmune encephalomyelitis [66], illustrating the dual role of inflammation after a tissue injury [67].

Temporal analyses of microglial phenotypes in animal stroke models showed an increase in the M1 phenotype in the first 14 days post-stroke, while M2 phenotypes were detected $12 \mathrm{~h}$ after the ischemic insult and increased during the first 3 days, followed by a decline in their number [55].

After transient middle cerebral artery occlusion in mice, microglial and macrophage infiltration peaks at 48-72 $\mathrm{h}$ after the ischemic insult [68]. Transient middle cerebral artery occlusion as short as $15 \mathrm{~min}$ in spontaneously hypertensive stroke-prone rats led to microglial activation [69], after which these cells migrated toward the ischemic lesion and remained close to the neurons in a process called "capping", which contributed to rapid removal of damaged neurons [28,70]. The production of ROS (mainly via NADPH oxidase (NOX)), matrix metalloproteinases, and cytokines, as well as activation of CD14 receptors by iNOS followed by the expression of TLR4 in activated microglia, increased its neurotoxic effects in the infarcted core as well as in the penumbra [71-73]. TLR4 depletion in mice reduced the magnitude of ischemic damage [74], as did inhibition of microglial activation (with $2 \%$ isoflurane) in rats subjected to transient focal cerebral ischemia [75]. However, the ablation of proliferating activated microglia impaired the production of IGF1 within the injured tissue [76], while transplantation of cultured microglia into the ischemic brain diminished the extent of ischemic damage and enhanced functional recovery [77].

In humans, histological studies and, more recently, positron emission tomography studies have shown abundant activated microglia in the ischemic core within $24-48 \mathrm{~h}$ after stroke onset [78], which persisted for several weeks, mainly at the periphery of the ischemic core [79]. Activated microglia were also detected in the thalamus ipsilateral to the infarcted hemisphere 7 days after stroke onset [80], a finding ascribed to the secondary degeneration of fibers. The persistence of activated microglia in the subacute phase of stroke in the penumbra makes the pharmacological manipulation of microglia an attractive possibility [81]. In the chronic phase, M2-polarized microglia, by producing a variety of neurotrophic factors, promote neuroplasticity and neurogenesis [82]. 


\subsubsection{Astrocytes in Post-Stroke Neuroinflammation}

Astrocytes are essential housekeeping cells supporting neuronal function by regulating the ion-water balance; removing excess neurotransmitters and waste products; secreting trophic factors such as fibroblast growth factor-2, brain-derived neurotrophic factor, and nerve growth factor; and, through their end feet, participating in the normal structure and function of the BBB [83].

Following ischemia, the impaired expression of the excitatory amino acid transporter 2 (EAAT2) interferes with the clearance of glutamate by astrocytes [84], while cytokines derived from neurons and glial cells lead to astrocytic hyperplasia and activation [85]. Activated astrocytes release vimentin, Il- $1 \beta$, monocyte chemotactic protein- 1 , and glial fibrillary acidic protein (GFAP) and contribute to the formation of glial scars [86] as well as MMP-2, which weakens the BBB [87].

In animal experiments, astrocytic activation started $4 \mathrm{~h}$ after the insult, peaked on day 4, and persisted for 28 days [88]. An important cytokine whose expression is increased in astrocytes after ischemia is IL-15 [28]. Transgenic mice expressing IL-15 with GFAP promoter exhibited worse neurological deficits following cerebral ischemia [28], while IL-15 knockdown in mice diminished the infarct size [89].

\subsubsection{Leukocytes in Neuroinflammation after Acute Ischemic Stroke}

Leukocytes, mainly neutrophils [90], are among the first blood-derived immune cells entering the brain after cerebral ischemia, peaking at $48-72 \mathrm{~h}$ and rapidly declining afterwards [18]. Minutes to hours following the ischemic insult, ROS, cytokines, and chemokines released by the damaged tissue induce the expression of adhesion molecules on leukocytes and cerebral endothelial cells [28,91]. Cytokines such as TNF- $\alpha$ or IL-1 $\beta$ lead to the translocation of P-selectin to the nucleus and its expression on the endothelial cells, which, by interaction with its receptor, PSGL-1, on leukocytes, slows the latter down, leading to leukocyte "rolling" on the endothelium. Further, the expression of intercellular adhesion molecule (ICAM)- 1 and vascular cell adhesion molecule (VCAM)- 1 on the endothelial cell surface and their interaction with the leukocyte $\beta 2$ integrins CD11a/CD18 and CD11b/CD18 lead to their firm adhesion and aggregation on the endothelial surface $[15,91,92]$. The leukocytes change their shape, become flattened, and redistribute adhesion, signaling, and receptor proteins toward an edge from which processes extend [26]. The expression of platelet endothelial cell adhesion molecule-1 (PECAM-1) along the endothelial cell junction, as well as the expression of the junctional proteins JAM-A and JAM-B by pericytes, facilitates neutrophil diapedesis across the BBB [93,94], as illustrated in Figure 1. Once in the tissue, leukocytes produce a series of factors which exacerbate tissue injury, such as ROS, proteases, IL-1, IL-6, IL-12, and TNF $\alpha$ [26,95].

The various subtypes of leukocytes which infiltrate the brain parenchyma after an ischemic stroke contribute to cerebral injury in many ways. Adherence of leukocytes to the endothelium can block erythrocytes in the microvasculature ("clogging"), leading to the "no-reflow" phenomenon [97]. In addition, activated leukocytes produce ROS, proteases, and matrix metalloproteinases (especially MMP-9), which damage the blood vessel wall and surrounding brain tissue [98]. Phospholipases in activated leukocytes produce biologically active substances such as prostaglandins, leukotrienes, and eicosanoids, which lead to vasoconstriction and platelet aggregation. In addition, by releasing pro-inflammatory factors, infiltrated leukocytes further promote neuronal injury [28,99].

Among the leukocytes infiltrating the brain are blood-derived monocytes/macrophages, which infiltrate the cerebral tissue in the hyperacute stage of stroke $(<24 \mathrm{~h})$ [100]. They have similar functions to resident microglia and are very difficult to differentiate from the latter [43], with researchers using chimera mice with enhanced colored fluorescent protein bone marrow for this aim [101]. Blood-derived macrophages peak by day 7, followed by a decline in their number. 


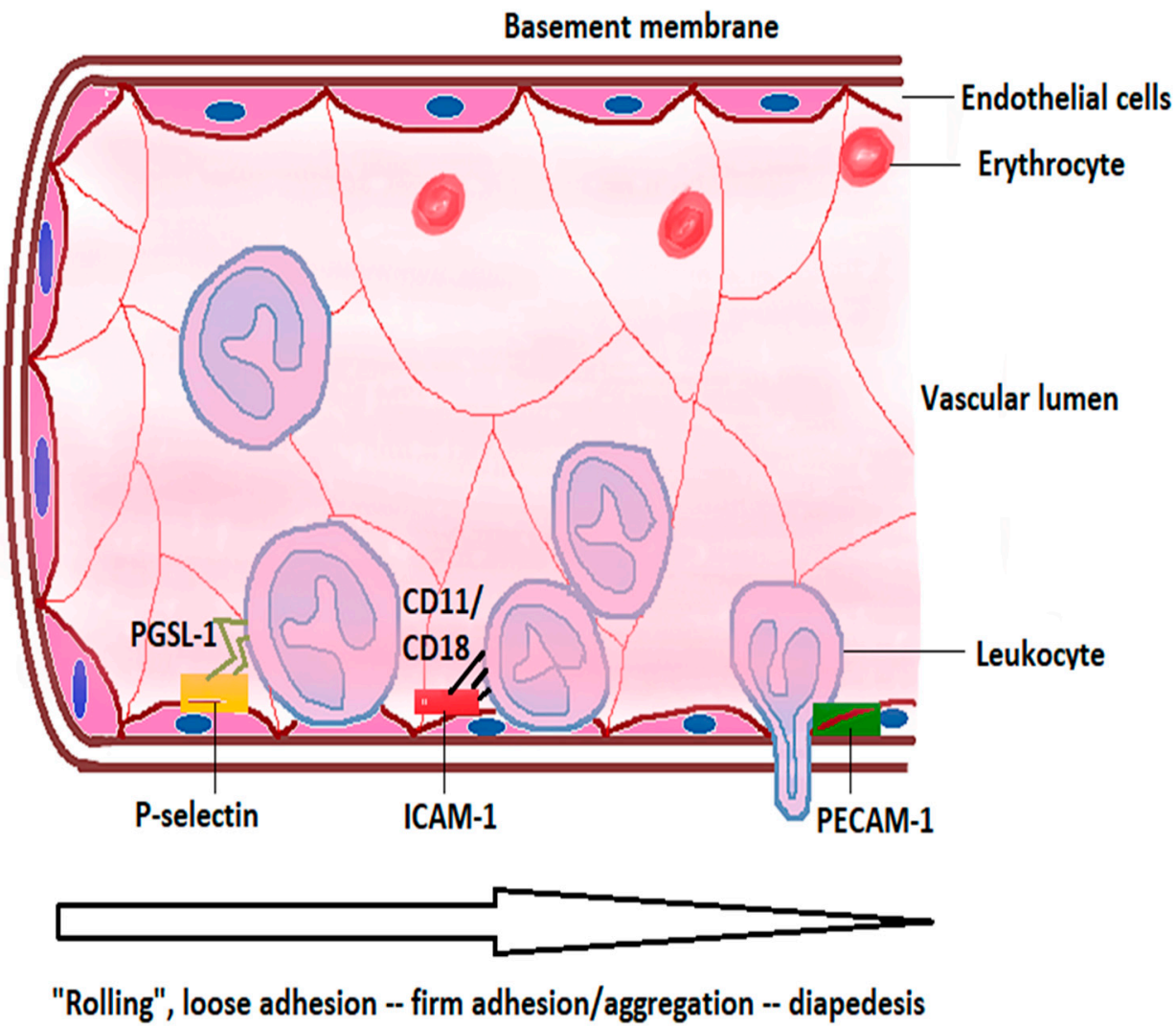

Figure 1. Leukocyte diapedesis. Leukocytes interact with endothelial cells expressing P-selectins through P-selectin glycoprotein 1 (PSGL-1), leading to their "rolling" on the endothelial surface. Interaction of leukocyte integrins CD11a/CD18 and CD11b/CD18 with intercellular adhesion molecule 1 (ICAM-1) leads to firm adherence and aggregation of leukocytes. Diapedesis of leukocytes is facilitated by the expression of platelet endothelial cell adhesion molecule 1 (PECAM-1) by endothelial cells. Adapted from Collard and Gelman [96].

Neutrophils start infiltrating the ischemic tissue after $30 \mathrm{~min}$ and peak between days 1 and 3, after which their number declines [102]. In the first 3 days following ischemia, neutrophils are the predominant inflammatory cells present in ischemic tissue [68], and their presence has been positively correlated with infarct size and neurological functional impairment [102].

Lymphocytes have less important contributions in cerebral ischemic injury; the mechanisms are mainly related to the innate T cell functions [103]. IL-17 secreting $\gamma \delta \mathrm{T}$ cells, $\mathrm{CD}^{+} \mathrm{T}$ cells, and $\mathrm{CD} 8^{+} \mathrm{T}$ cells may infiltrate the parenchyma within hours after stroke onset, peak by day 3, and aggravate ischemic injury [68,103,104], as do natural killer T cells [105], while regulatory lymphocytes (Tregs) expressing the forkhead box P3 (Foxp3) transcription factor $[106,107]$ have traditionally been regarded as exhibiting neuroprotective activity $[108,109]$. The choroid plexuses appear to be the preferential route for infiltration by lymphocytes since in an experimental setting, infarction of the choroid plexus resulted in diminished lymphocyte infiltration [110].

In the early post-stroke phase, Tregs act on peripheral leucocytes to inhibit the production of matrix metalloproteinase-9 (MMP-9) by neutrophils [111,112], thereby protecting the blood-brain barrier, and prevent the activation of effector $\mathrm{T}$ cells by secreting antiinflammatory IL-10 and TGF- $\beta$ [113]. However, by having a higher adhesive propensity, natural Tregs interact in the hyperacute phase of ischemic stroke with activated endothelial cells and platelets, leading to microvascular dysfunction and thrombus formation, resulting in impaired reperfusion [114]. Selective depletion of Tregs in mice significantly reduced infarct size and improved functional recovery [114] in a transient middle cerebral artery occlusion model. In later stages, 5 to 7 days after stroke onset, Tregs infiltrate the brain parenchyma, prevent microglia/macrophage polarization toward the M1 pheno- 
type, driving microglial polarization toward the M2 phenotype, and inhibit astrocytic activation through the amphiregulin (AREG)/epidermal growth factor receptor (EGFR) pathway $[115,116]$. In addition, through producing IL-10, which interacts with the IL-10 receptor expressed on neural stem cells, Tregs promote the proliferation of these cells in the subventricular zone as well as the migration of neural progenitor cells to the injured area and their differentiation into mature neurons [117].

\subsubsection{Platelets in Cerebral Ischemia/Reperfusion Injury}

During ischemia and energy failure, there is a build-up of hypoxanthine which, upon reperfusion, will be converted by hypoxanthine oxidase to xanthine and uric acid, with significant amounts of superoxide generated in the process [118]. In addition, dysfunctional mitochondria and leukocyte NADPH oxidases also produce ROS during reperfusion [118], which can activate platelets and enhance their activity by quenching NO and decreasing cyclic guanosine monophosphate and protein kinase $\mathrm{G}$ activity inside the platelets [119-121] This leads to altered calcium signaling and platelet activation, adhesion, and aggregation $[119,120]$, as well as vasoconstriction (also caused by limited availability of NO), both of which are involved in the no-reflow phenomenon following reperfusion [122].

In response to hypoxia, and additionally stimulated by uric acid [123], endothelial cells release von Willebrand factor (VWF) stored in Weibel-Palade bodies into the media. Activated platelets are additional sources of VWF. VWF is secreted as large, highly thrombotic polymers cleaved into smaller fragments by disintegrin-like and metalloprotease with thrombospondin type 1 motif number 13 (ADAMTS 13) [124]. Genetic deletion of ADAMTS 13 resulted in increased infarctions after experimentally induced transient middle cerebral artery occlusion [125]. VWF contributes to platelet activation by binding glycoprotein $\mathrm{Ib}$ (GPIb) [119] and is also involved in leukocyte recruitment [126]. Recruited leukocytes phagocytose degraded cells, release supplemental amounts of ROS [127], and form complexes with platelets (platelet-neutrophil aggregates) which are implicated in capillary no-reflow as well, along with pericyte contraction [128,129].

A series of molecules released by damaged cells (DAMPs, HMGB1) interacts with platelet TLR 4 and promotes platelet activation and thrombus formation [130]. In addition, platelets can bind to activated endothelial cells via cell adhesion molecules (ICAM, VCAM), CD40-CD40L interactions, and selectins expressed by endothelium [131]. Electron microscopy studies have shown that following reperfusion endothelial denudation is worse compared to ischemia, creating the premises for platelets to interact with exposed collagen [132].

After activation, the content of platelet granules is released and serves to further increase platelet activation (adenosine diphosphate) or act as pro-inflammatory cytokines (such as platelet factor 4 and $\beta$-thromboglobulin) to activate endothelial cells and recruit additional leukocytes and form platelet-neutrophil aggregates [133]. Phosphatidylserine is exposed and mediates the conversion of prothrombin to thrombin by recruiting the coagulation factors Xa and Va [134].

However, platelet granules also contain factors which prevent the aggravation of ischemia/reperfusion injuries, especially hemorrhagic transformation [135]. Platelet inhibition with monoclonal antibodies such as abciximab, or with the synthetic molecule tirofiban, resulted in bleeding complications [136]. Moreover, platelets also release anti-inflammatory cytokines, such as IL-10 [137], as well as brain-derived neurotrophic factor (BDNF), stored in granules and platelet cytosol and released after the activation of thrombin receptors PAR1 and PAR4 [138]. After release, BDNF promotes neurogenesis, oligodendrogenesis, and remyelination of axons in the white matter $[90,139]$.

\subsection{Inflammatory Mediators}

2.3.1. Cytokines

Cytokines are small polypeptides (8-26 kDa), normally expressed at very low levels, which regulate immune responses [140]. Various cytokines can either mediate the inflamma- 
tory response or act as anti-inflammatory molecules, which terminate the inflammatory response.

\section{Pro-Inflammatory Response}

Necrotic neurons release DAMPs, or "hazard signals", which induce TLR4 on microglia and stimulate microglial cells to produce inflammatory cytokines via the NF- $\mathrm{B}$ pathway [141].

M1-polarized microglia will produce pro-inflammatory cytokines such as IL-1 $\beta$, IL-6, IL-18, and TNF- $\alpha$ [141]. The perivascular macrophages, lying between the brain surface and the vascular endothelial membrane, produce IL-1 $\beta$, IL-12, IL-23, TNF- $\alpha$, chemokines, and ROS [142]. T helper cells, once in the brain parenchyma, release ROS, IFN- $\gamma$, TNF- $\alpha$, IL-1 $\beta$, IL-17, and IL-21, damaging the neurons and neurovascular unit [143], while natural killer T cells are neurotoxic by releasing IL-2 and TNF- $\alpha$ [142].

The best-studied is the NLRP3 inflammasome, activated in two steps. First, DAMPs activate TLRs on immune cells, which induce the expression of inactive protein NLRP3 and pro-IL-1 $\beta$ via the NF-кB pathway $[144,145]$. Resting NLRP3 is situated at the endoplasmic reticulum. In step two, an effector domain (pyrin domain, or PYD) is oligomerized in the NLRP3 central domain, serving as a girder for ADC adaptor protein (apoptosis-associated speck-like protein containing a carboxy-terminal CARD), which combines with procaspase1 and forms the NLRP3 inflammasome [146]. This, in turn, by using the CARD (caspase activation and recruitment domain), activates procaspase- 1 to caspase- 1 and splits pro-IL$1 \beta$ into its active form [147], leading to pyroptosis, a specific type of cell death [141].

IL-1 occurs in 3 forms: IL-1 $\alpha$, IL-1 $\beta$, and IL-1ra [85]. IL-1 $\alpha$ is intracellular, while IL-1 $\beta$ is secreted extracellularly. IL-1ra is the antagonist of IL-1 $\beta$, the expression of which is induced by very high levels of IL-1 $\beta[85,148]$. Most researchers reported increased levels of IL-1 $\beta$ within $24 \mathrm{~h}$ after stroke onset [149], while others did not [150]. IL-1 $\beta$ exacerbates cerebral injury after an ischemic insult and significantly contributes to the disruption of the BBB. IL-1 $\beta$ administered to rats increased the magnitude of brain injury [151], while IL-1 $\beta$-deficient mice had smaller-volume infarcts compared with wild-type mice [152]. In clinical setting, patients treated with the recombinant human IL-1 receptor antagonist (IL-1Ra, or anakinra) had reduced circulating pro-inflammatory markers (TNF $\alpha$, IL-6, and IL-10) and better clinical outcome as compared to placebo [153]. The usefulness of anakinra in downregulating the inflammatory response was further proved in the recent COVID-19 pandemic [154,155].

Tumor necrosis factor (TNF)- $\alpha$ has two forms: a transmembrane form, involved in regulation of inflammation via cell-cell interactions (tmTNF- $\alpha$ ), and a soluble form $(\mathrm{sTNF}-\alpha)$, which increases the phagocytic and cytotoxic activity of macrophages and upregulates the expression of IL-1 $\beta$ and IL-6 [142,156-158]. TNF- $\alpha$ is upregulated after cerebral ischemia, and protein levels are increased by $3 \mathrm{~h}$ after ischemia, peaking up to 5 days after the insult [159]. The cytokine induces the release of matrix metalloproteinase- 9 (MMP-9) from pericytes, leading to increased permeability of the BBB [160]. However, other researchers have shown TNF- $\alpha$ to be neuroprotective and involved in ischemic preconditioning [161]. Thus, it appears that the dual role depends on the source of TNF- $\alpha$, with microglial-derived TNF- $\alpha$ being neuroprotective in stroke [140].

Both IL-1 $\beta$ and TNF are required for the synthesis of IL-6, released by microglia, astrocytes, neurons, and endothelial cells [162]. Within a few hours after stroke onset, there is a rise in the concentration of IL-6 [163], which correlates well with stroke severity and worse prognosis [164], although other researchers have found opposite results [163]. When analyzing the different stroke subtypes, it appeared that embolic strokes had the highest IL-6 levels [165].

IL-8 also promotes inflammatory responses in cerebral ischemia, proven by the reduced infarct size and better outcome after blocking the cytokine and its receptors [166,167].

Interferon gamma (IFN- $\gamma$ ) is another cytokine able to modulate immune responses and produced by various cell types, such as monocytes, macrophages, and B and T lymphocytes, 
as well as natural killer cells [85]. It can activate multiple downstream signaling cascades, such as the Janus kinase (JAK)-signal transducer and activator of transcription (STAT) pathway, and modulates microglial polarization [85].

Other pro-inflammatory cytokines are IL-16, IL-17, IL-18, monocyte chemotactic protein 1 (MCP-1), and leukotrienes [13].

\section{Anti-Inflammatory Cytokines}

In the subacute phase, M2-polarized microglia start producing anti-inflammatory cytokines, such as IL-10, IL-4, and transforming growth factor-beta (TGF- $\beta$ ), which will lead to inhibition of the inflammatory response [144].

IL-10 is an anti-inflammatory cytokine produced by various cell types, such as monocytes, CD4, CD25, Foxp3 regulatory T cells, and mastocytes [168]. IL-10 is upregulated in ischemic stroke, peaking 3 days after the onset [169]. It can counterbalance the actions of IL-1 $\beta$ and TNF- $\alpha$, protecting against injury in ischemic stroke $[13,170]$. Animal research with intraventricular administration of IL-10 or adenoviral delivery of the IL-10 gene confirmed the neuroprotective effect of this cytokine [171,172]. In human patients, low plasma levels of IL-10 in the first hours after stroke onset were associated with worse neurological deficits at $48 \mathrm{~h}$ [173].

While IFN- $\gamma$ is a pro-inflammatory cytokine, interferon- $\beta$ (IFN- $\beta$ ) has been used as immunomodulatory treatment in multiple sclerosis, where it reduces MMP-9 levels and diminishes BBB disruption [174,175]. In an experimental setting, IFN- $\beta$ downregulated ICAM-1 expression on cerebral endothelial cells and attenuated BBB disruption and neutrophil infiltration in a rat model of stroke, thereby reducing infarct volume $[176,177]$.

Transforming growth factor-beta (TGF- $\beta$ ), although rarely expressed in normal brain, has been found significantly upregulated after stroke, being produced by microglia, macrophages, neurons, and astrocytes [140]. TGF- $\beta 3$ is especially involved in neuronal survival and tissue recovery [85]. In an experimental setting, antagonizing TGF- $\beta$ resulted in increased infarct volume [178], while intranasal administration of TGF- $\beta$ reduced infarct volume and enhanced neurogenesis after ischemic stroke in mice [179].

IL-4 is able to polarize microglia toward the anti-inflammatory M2 phenotype [180], indirectly supporting cell survival and tissue repair [181].

\subsubsection{Chemokines}

Chemokines, or chemotactic cytokines, are low-molecular-weight proteins (8-10 kDa) with an $N$-terminal domain, a $\beta$-sheet subunit, and a $C$-terminal $\alpha$-helix that are involved in cellular activation and leukocyte recruitment. Their main function is to control leukocyte migration into tissues during inflammation [141]. Depending on the number and location of cysteine residues, they can be divided into [182]:

- CC-two cysteine residues, immediately adjacent,

- $\quad$ CXC - two cysteine residues separated by one amino acid,

- $\quad$ CX3C - two cysteine residues separated by three amino acids.

Chemokines are released by neurons, astrocytes, microglial cells, oligodendrocytes, and endothelial cells [183] and act under normal conditions mainly as trophic and protective modules in the nervous system. Their role in ischemic stroke pathogenesis is still controversial.

Monocyte chemoattractant protein-1 (MCP-1) directly increases the permeability of the BBB by causing tight junction proteins to redistribute in endothelial cells [184] and also recruits monocytes and activated lymphocytes into the brain after an ischemic insult [185]. Mice lacking MCP-1 receptors have reduced infarct size, reduced BBB permeability, and diminished edema compared to wild-type mice following transient focal cerebral ischemia [186].

Other chemokines upregulated in the first $3 \mathrm{~h}$ after stroke are microglial response factor1 (MRF-1), fractalkine (CX3CL1), and macrophage inflammatory protein 1 (MIP-1), which all contribute to the infiltration of the injured tissue with inflammatory cells and thus weaken the BBB [22]. However, the role of fractalkine is still under investigation, with research 
pointing towards a dual role, being both neuroprotective and pro-inflammatory [184,185]. A knock-out of CX3CL1 and CX3CL1 receptors resulted in reduced lesion volume after middle cerebral artery occlusion [187]. On the other hand, exogenous fractalkine administered shortly before middle cerebral artery occlusion to wild-type animals resulted in diminished size of the subsequent lesion, increased lesion size in CX3CL1 knock-out animals, and had no effect on animals lacking CX3CL1 receptors [188]. It appears that the neuroprotective effect of fractalkine depends on its interaction with microglia [184]. CCL5 is another chemokine studied, with research revealing reduced infarct volume in a middle cerebral artery occlusion in CCL5 knock-out mice [189].

Stromal cell-derived factor 1 (SDF-1), also known as CXC motif chemokine 12 (CXCL12), also seems to have a dual role. SDF-1 and its receptor were found upregulated in the penumbral area [190], and rats treated with antagonists of SDF-1 receptors had improved functional outcome after stroke [191]. However, other researchers emphasized the neuroprotective role of SDF-1, showing that it facilitates the homing of bone marrow stromal cells to the tissue injured by ischemia [192], thereby reducing the size of infarction and enhancing neural plasticity [193].

\subsubsection{Matrix Metalloproteinases}

Although not inflammatory mediators, matrix metalloproteinases (MMPs) are tightly related to neuroinflammation and contribute significantly to BBB disruption, cerebral edema, and hemorrhagic transformation. MMPs are a family of proteolytic enzymes which have a catalytic zinc site, a pro-peptide region, a fibronectin binding site, and a transmembrane site [28]. They can be either constitutive, acting close to the site of activation (MMP-2, MMP-14), or inducible (MMP-3, MMP-9), acting at distant sites [194]. Although traditionally regarded as pro-inflammatory enzymes with deleterious effects in stroke pathophysiology, research has shown that they are also involved in neuronal regeneration, angiogenesis, and cell proliferation [195].

Upon activation of the constitutive MMPs, such as MMP-2, they fragment the tight junction proteins which "zip" endothelial cells, leading to a transient opening of the BBB 2 to $3 \mathrm{~h}$ after reperfusion $[196,197]$. After this early phase of BBB dysfunction, its integrity is restored until $24-48 \mathrm{~h}$ after the ischemic insult, when a second opening of the BBB is described with more dramatic consequences, such as cerebral edema, hemorrhagic transformation, and leukocyte infiltration, due to the expression and activation of inducible MMPs, such as MMP-3 and MMP-9 [198]. MMP inhibitors were able to reduce infarct size and edema in animal models of stroke, but their clinical use is hampered by their pharmacokinetic profile and significant toxicity $[198,199]$. Inducible MMPs, being free to move in the extracellular space, are able to inflict greater damage on the extracellular matrix and basal lamina [28]. Further, tissue plasminogen itself, if given during the early opening of the $\mathrm{BBB}$, is able to get access into the cerebral parenchyma and upregulate inducible MMPs, which will lead to BBB damage with hemorrhagic complications and edema [196].

On the other hand, plasma levels of MMP-3 were found increased in patients with better functional and motor recovery [200], highlighting the dual role of these enzymes in stroke pathogenesis and recovery, while 1-2 weeks following stroke onset, MMP-9 is upregulated in the peri-infarct zone and colocalizes with markers of neurovascular remodeling [201], a process which likely involves the processing of VEGF (vascular endothelial growth factor). MMP-9 is able to transform pro-VEGF and matrix-bound VEGF into active molecules [202]. In fact, delayed inhibition of MMPs, starting with day 7, worsened outcome after stroke [201], suggesting that modulation of MMPs instead of blocking them would be a more rewarding approach.

Table 2 summarizes the beneficial and detrimental effects of the main inflammatory molecules in ischemic stroke, and Figure 2 schematically presents the temporal profile of the neuroinflammatory pathways. 
Table 2. Beneficial and detrimental effects of the main inflammatory mediators. Adapted from Jayaraj et al. [28].

\begin{tabular}{|c|c|c|c|}
\hline Inflammatory Mediators & Beneficial Effects & Detrimental Effects & References \\
\hline TNF- $\alpha$ & $\begin{array}{l}\text { Stimulates the expression of } \\
\text { antioxidants and } \\
\text { anti-apoptotic factors, } \\
\text { involved in ischemic } \\
\text { preconditioning, increases } \\
\text { expression of neurotrophic } \\
\text { factors, modulates } \\
\text { neuronal plasticity }\end{array}$ & $\begin{array}{c}\text { Increases infarct volume, } \\
\text { promotes leukocyte adherence } \\
\text { to endothelium, contributes to } \\
\text { BBB disruption, edema } \\
\text { formation, increases apoptosis } \\
\text { of endothelial cells }\end{array}$ & {$[15,28,91,92,152,160,161,203]$} \\
\hline IL-6 & $\begin{array}{c}\text { Enhances } \\
\text { post-stroke angiogenesis }\end{array}$ & $\begin{array}{c}\text { Contributes to leukocyte } \\
\text { recruitment and promotes } \\
\text { neuroinflammation, increases } \\
\text { stroke severity }\end{array}$ & {$[28,164]$} \\
\hline IL-8 & & Augments neuroinflammation & {$[28,166,167]$} \\
\hline IL-10 & $\begin{array}{c}\text { Diminishes cytokine release, } \\
\text { promotes neuronal survival } \\
\text { and neurogenesis, promotes } \\
\text { M2 polarization of } \\
\text { microglia/macrophages }\end{array}$ & & {$[28,40,52,117]$} \\
\hline IL-1 $\beta$ & & $\begin{array}{c}\text { Disruption of BBB, edema } \\
\text { formation, } \\
\text { leukocyte recruitment }\end{array}$ & {$[28,59,151]$} \\
\hline MMPs & Promote vascular remodeling & $\begin{array}{l}\text { BBB disruption, vasogenic } \\
\text { edema, } \\
\text { hemorrhagic transformation }\end{array}$ & {$[28,196,201]$} \\
\hline Interferon- $\beta$ & $\begin{array}{c}\text { Downregulates ICAM-1 } \\
\text { expression, } \\
\text { attenuates BBB disruption }\end{array}$ & & {$[176,177]$} \\
\hline
\end{tabular}

Increases BBB permeability, enhances

leukocyte infiltration
$[28,184,185]$

BBB-blood-brain barrier; IL-interleukin; MCP-1—monocyte chemotactic protein 1; MMPs-matrix metalloproteinases; TNF- $\alpha$-tumor necrosis factor- $\alpha$.

\subsubsection{Neurotrophic Factors and Neuropeptides}

Although the central nervous system has a limited ability to regenerate, neurogenesis is still possible in the subventricular zone and the subgranular zone of the dentate gyrus [205], although it declines with age. This process occurs in three steps [206]: (1) neural stem cell proliferation, (2) migration of neuroblasts and immature neurons, and (3) differentiation into mature neurons and synaptogenesis. Following ischemic stroke, neural stem cells migrate into the peri-infarct region and differentiate into neurons [207]. However, in an inflammatory environment lacking trophic factors, many of these immature neurons will not survive [208], which is why the role of various neurotrophic factors and the possibility of their upregulation has been investigated as a means of enhancing post-stroke recovery. Research has shown that insulin-like growth factor 1 (IGF-1), brain-derived neurotrophic factor (BDNF), and vascular endothelial growth factor (VEGF) are involved in neural stem cell proliferation, while stromal-derived factor 1, MCP-1, and MMPs 2, 3, and 9 mainly influence the migration of neuroblasts [209-213]. Angiogenesis, defined as the sprouting of preexisting vessels leading to the formation of new blood vessels, is closely intertwined with neurogenesis after stroke $[214,215]$ and even precedes the neurogenic processes after an ischemic insult [216]. 


\section{A. Early mechanisms}

minutes

1 - 2 hours

4 - 6 hours

24 hours

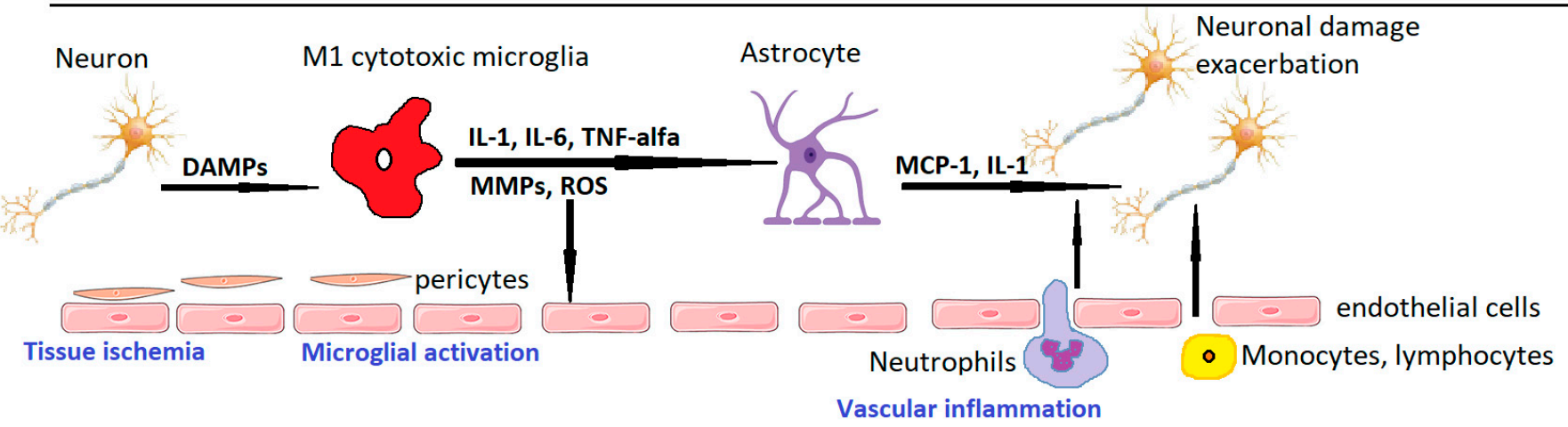

\section{B. Delayed mechanisms}

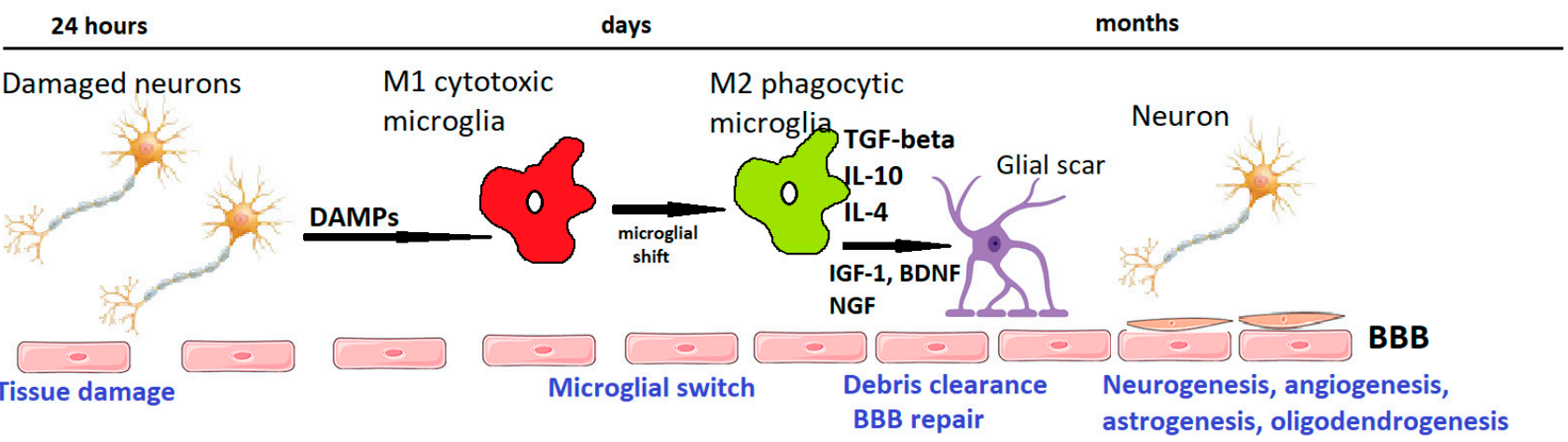

Figure 2. Temporal profile of post-stroke ischemic pathways. Immediately after ischemic stroke, neurons release damage-associated molecular patterns (DAMPs) which lead to microglial and endothelial activation. M1-polarized microglia release pro-inflammatory interleukins (IL-1, IL-6, tumor necrosis factor-alpha), as well as matrix metalloproteinases (MMPs) and reactive oxygen species (ROS), which weaken the blood-brain barrier (BBB). Pericytes and astrocytic endfeet are lifted from the basement membranes. A "leaky" BBB allows leukocytes to infiltrate the cerebral parenchyma, where they produce pro-inflammatory factors (IL-1, monocyte chemotactic protein 1 (MCP-1)) and exacerbate tissue injury. In the delayed subacute phase, microglial switch to an M2 phenotype leads to tissular debris clearance, and, by expressing anti-inflammatory mediators and neurotrophic factors such as insulin-like growth factor 1 (IGF-1), brain-derived neurotrophic factor (BDNF), or nerve growth factor (NGF), promotes glial scar formation as well as BBB repair, neurogenesis, astrogenesis, oligodendrogenesis, and angiogenesis. Adapted from Rajkovic et al. [204].

The link between neuroinflammation and neurogenesis is complex, with the former being able to both suppress and promote neurogenesis [206]. For example, short-term treatment of neural stem cells with IL-6 in vitro promotes cell division [217], while chronic astrocytic IL-6 expression impairs neurogenesis in the dentate gyrus of mice [218]. IL-17 released by astrocytes also promote neurogenesis via the NF- $\kappa$ B pathway [219]. Microglia have dual effects, being able to produce cytokines which impair neuronal survival as well as trophic factors which guide neural stem cell migration and support differentiation [220].

However, since most of these newly formed neurons die within 2-5 weeks [208], it is important to provide an environment rich in neurotrophic factors to promote their survival and integration into neuronal circuits. Unfortunately, most of these trophic factors are large molecules which hardly cross the BBB, making exogenous administration challenging. As such, several delivery strategies have been developed.

Central administration of IGF-1 prevented white matter lesions after hypoxic-ischemic insult in rat brain [221], but the molecule has limited bioavailability [222] and concerning metabolic and mitogenic effects [223]. A naturally cleaved tripeptide, glycine-proline- 
glutamate (GPE), retains the neuroprotective properties of the original molecule and can be safely administered intravenously 3-7 $\mathrm{h}$ after the ischemic insult [223], resulting in significantly improved outcome regardless of the animal's age [224]. The peptide does not bind to IGF-1 receptors but activates NMDA receptors [225] and inhibits caspase-dependent and -independent apoptosis [224].

Extensive studies have reported on the neuroprotective effects of BDNF in various diseases of the CNS, from neurodegenerative ones to traumatic and vascular insults [226,227]. With important roles during development, BDNF exerts its neuroprotective functions after binding to tyrosine kinase receptors mainly through the phosphatidylinositol 3-kinase (PI3K)/Akt and the mitogen-activated protein kinase/extracellular-signal- regulated kinase (MAPK/ERK) pathways [228], which activate transcription factors such as AP1, NF- $\mathrm{B}$, and FOXOs, and induces genes encoding antioxidant enzymes, anti-apoptotic proteins, and proteins involved in ion homeostasis [229]. In addition, BDNF can induce local calcium influxes in neurites [230] and promote neurogenesis and dendritic outgrowth [138,231]. Increasing BDNF levels with medication, such as cilostazol [232], and delivering BDNF overexpressing fibroblasts or mesenchymal cells [233,234] or through exercise [235] improved post-stroke recovery. However, it also has a low transport rate across the BBB and, due to the involvement of tyrosine kinase $B$ receptors in the regulation of metabolism and energy homeostasis [236], it carries the risk of weight loss. Improved delivery was achieved by incorporating polyethylene glycol (PEG) moieties [237], nanoparticle formulations [238], or fusion with viral-derived peptides [239].

The expression of nerve growth factor (NGF) and tyrosine kinase receptor $\mathrm{A}$ is rapidly upregulated following ischemia [240], promoting axonal sprouting and tissue repair [241]. However, in clinical trials, the systemic administration of NGF led to weight loss and myalgias [242].

Glial-cell-line-derived neurotrophic factor (GDNF) acts by binding to the extracellular glycosylphosphatidylinositol (GPI)-linked receptor, GFR $\alpha 1$, and the transmembrane tyrosine kinase, c-Ret [243], the expression of which is upregulated in the penumbral area [244]. Exogenous GDNF delivery yielded conflicting results: while short-term delivery proved neuroprotective [245], long-term elevated GDNF levels can exacerbate neuronal death [246]. Research has shown an enhanced neurogenesis mainly in the striatum [247], which is why this neurotrophin has been more extensively evaluated in Parkinson's disease [248].

Other proteins and peptides have also been shown to promote tissue repair after stroke. One such protein is annexin A1, a calcium- and phospholipid-binding protein, with antiinflammatory actions mediated through the G-protein-coupled formyl peptide receptor type 2 [249], which promotes microglial M2 polarization [250]. In a mouse stroke model, annexin A1 was found reduced at the onset of ischemia, followed by a return to normal levels after successful recanalization. Exogenous administration of the biologically active Nterminal peptide during reperfusion resulted in a diminished magnitude of tissue damage, likely due to a shift of microglia/macrophage cells toward M2 phenotypes via activation of the AMPK-mTOR pathway [251]. Leptin, a well-known hormone related to obesity, has also been shown to exhibit anti-inflammatory actions and to promote neuroprotection, cell differentiation, mitochondrial biogenesis, and angiogenesis [252], as well as to upregulate antioxidant defenses and anti-apoptotic proteins [253]. It exerts its effects through activation of the Janus kinase (JAK)-signal transducer and activator of transcription (STAT) [254], the Ras/extracellular signal-regulated kinase (ERK)1/2 [255], the adenosine monophosphate kinase (AMPK)-mammalian target of rapamycin (mTOR) [256], and the phosphoinositide-3 kinase (PI3K) / Akt pathways [257].

\section{Therapeutic Approaches Focusing on Modulation of Neuroinflammation}

Although promising in preclinical studies, the clinical trials targeting stroke immunology have not shown clear benefits despite strategies addressing both innate and adaptive immune responses [20]. The dual role of the inflammatory response, promoting cellular injury in the acute setting and restoration of the cellular functions during rehabilitation, 
is a major challenge for clinical trials targeting neuroinflammation. For example, microglial P2X4 receptors modulate the inflammatory response after ischemia, but in acute cerebral ischemia, the activation of these receptors leads to exacerbation of the inflammatory response, while their activation in chronic ischemia results in the release of BDNF, which supports synaptic plasticity. As such, microglial P2X4 receptor deletion is protective against acute cerebral ischemia but exacerbates behavioral abnormalities in the post-stroke rehabilitation process [258].

\subsection{Therapies Targeting Microglia}

Minocycline, a highly lipophilic antibiotic agent able to cross the BBB, was shown to be able to inhibit microglial activation, diminish the magnitude of neuronal apoptosis [259], decrease the rate of $\mathrm{T}$ cells migration, reduce the expression of chemokines and their receptors as well as the production of free radicals [260], and inhibit matrix metalloproteinases. In preclinical setting, minocycline diminished infarct size and hemorrhagic transformation [261] and did not interact with recombinant tissue plasminogen activator [262]. As such, minocycline administered within $24 \mathrm{~h}$ from stroke onset and continued for 5 days was evaluated in two phase 2 clinical trials alone or in combination with rtPA, which showed it to be safe, well tolerated, and potentially effective [263,264]. However, a third study, possibly underpowered, confirmed the safety but dismissed the efficacy of minocycline in acute ischemic stroke [265].

Among the receptors involved in microglial M1 polarization are TLR4 receptors [266]. In preclinical studies, the inhibition of TLR4 resulted in reduced infarct size and improved recovery in diabetic rats [267] A phase 1b/2a trial (NCT 04734548) is currently recruiting 151 patients eligible for endovascular treatment to evaluate the safety of inhibiting TLR4 receptors with ApTOLL [268].

In preclinical studies, the angiotensin II type 2 receptor agonist C21, administered 3 days after stroke onset, improved functional outcome by reducing neuroinflammation and shifting microglia toward the M2 phenotype $[269,270]$.

Recent research focuses on influencing microglial polarization from M1 to M2 phenotype by using IL-4 or IL-33 in a preclinical setting [271,272].

\subsection{Strategies for Blocking Neutrophil Infiltration}

Several trials have focused on targeting leukocyte adhesion and transmigration as an anti-inflammatory treatment in acute ischemic stroke. A murine ICAM-1 antibody, enlimomab, interferes with leukocyte adhesion and was shown in experimental studies to reduce infarct size $[273,274]$. However, in a clinical trial, enlimomab administered within $6 \mathrm{~h}$ after stroke onset increased the rate of adverse events and significantly worsened the outcome of stroke patients [275].

A cellular adhesion molecule located on the leukocyte surface, L-selectin, has been targeted with a humanized monoclonal antibody (HuDREG200) alone or in combination with alteplase in a rabbit stroke model, but the results have not been disclosed [276].

Another humanized antibody targeting neutrophil adhesion, Hu23F2G, or LeukArrest, was tested in the HALT study, a phase 3 clinical trial which, although it was shown to improve the modified Rankin score at 3 months in a phase 2 study, was prematurely stopped by the sponsor due to lack of benefit suggested by an interim analysis [97].

Preclinical studies suggested that targeting CD11/CD18 for blocking neutrophil infiltration was beneficial only in transient ischemic stroke models and had no effect in permanent ones [277,278]. The ASTIN (Acute Stroke Therapy by Inhibition of Neutrophils) trial, tested a CD18 antagonist inhibiting polymorphonuclear adhesion and transmigration, namely UK-279,276, administered within $6 \mathrm{~h}$ from stroke onset on stroke outcome. Similar to the HALT trial, it was stopped early after futility criteria were reached [279].

Natalizumab, an anti-CD49b antibody, used in the immunomodulatory treatment of multiple sclerosis, has been tested in preclinical studies in ischemic stroke with conflicting results: one study showed no effect [280], while four studies suggested positive 
effects [281,282]. To further complicate the issue, a large preclinical trial concluded that the effectiveness of CD49d antibodies in stroke depends on infarct size and location, showing reduced leukocyte infiltration and lesion volume after permanent distal occlusion of the middle cerebral artery but not after transient occlusion of the proximal portion of the same artery [283]. In a clinical setting, natalizumab administered within $9 \mathrm{~h}$ after stroke onset (ACTION trial, NCT 01955707) did not reduce lesion size, but at 30 days, the outcome of patients in the treatment arm was better, an effect lost at the 90-day follow-up [284]. A second recently completed phase 2 clinical trial with 277 participants, ACTION II (NCT02730455), evaluated the effects of two different doses of natalizumab, given either within $9 \mathrm{~h}$ or between 9 and $24 \mathrm{~h}$ after stroke onset, on functional recovery [285].

\subsection{Targeting Lymphocytes in Acute Ischemic Stroke}

Since lymphocytes interfere in the delayed phase of ischemic injury, therapeutic strategies targeting these cells would theoretically have wide therapeutic windows.

Preclinical studies suggested that blocking cerebral invasion of pro-inflammatory lymphocytes $(\mathrm{TH} 1, \mathrm{TH} 17, \gamma \delta \mathrm{T}$ ) would be neuroprotective $[104,286]$. Interferon $\beta-1 \mathrm{a}$, long used as immunomodulatory treatment in multiple sclerosis, prevents BBB disruption; reduces the proliferation and activation of T helper, $\gamma \delta \mathrm{T}$ cells, and CD8+ cells; and inhibits the production of pro-inflammatory cytokines [287]. The safety of four doses ranging from 11 to $88 \mathrm{mcg}$ of interferon $\beta$-1a daily for 7 days in acute ischemic stroke was evaluated in a phase 1 clinical trial (NCT 00097318) in 60 patients, but no results have yet been published [268].

Regulatory T cells (Tregs) have been traditionally viewed as anti-inflammatory lymphocytes, but their therapeutic manipulation in different stroke models yielded divergent results. Treg depletion led to increased infarct sizes in three studies [288-290], and one study found a reduced infarct size in Treg-deficient mice [111], while other studies could not detect any influence on infarct size [111,291]. The different findings were explained by the various experimental models used and infarct sizes [20]. Apparently, Treg depletion is beneficial only in small infarcts in permanent occlusion models [113]. An opposite approach, transferring Tregs to wild-type animals or administering a CD28 superagonist, which expands the number of Tregs and amplifies their suppressive function, also resulted in divergent results, with the strategy either improving stroke outcome [292] or increasing infarct size [293]. One explanation of these divergent findings relates to the involvement of Tregs in microvascular thrombus formation and their contribution to secondary ischemia occurring after reperfusion, an event which does not occur in permanent focal ischemia stroke models [114].

Fingolimod, a drug approved for the treatment of multiple sclerosis, inhibits lymphocyte trafficking and infiltration of the central nervous system. Tested in models of transient and permanent focal ischemia, it did not influence lesion size and behavioral dysfunction [20]. A pilot phase 2 trial enrolling 22 participants (NCT02002390) who received $0.5 \mathrm{mg}$ daily for 3 days suggested favorable effects on outcome, with smaller infarct sizes and reduced rates of bleeding [294], and demonstrated safety of the association of alteplase with fingolimod. Two other phase 2 studies are ongoing with fingolimod. One phase 2 trial aiming at enrolling 118 patients will assess outcome in patients receiving $0.5 \mathrm{mg}$ fingolimod daily for 3 consecutive days started $1 \mathrm{~h}$ before thrombectomy (NCT 04675762), a trial in which standard stroke care also involves bridging between alteplase and mechanical thrombectomy, while a second phase 2 trial will assess collateral circulation in 30 patients randomized to receive either $0.5 \mathrm{mg}$ fingolimod or placebo daily for 3 days starting $3 \mathrm{~h}$ prior to endovascular treatment (NCT 04629872) [268].

\subsection{Other Drugs Which Modulate Neuroinflammation}

1. Due to the potential of oxidative stress to elicit inflammatory responses, antioxidant molecules could act as anti-inflammatory agents as well. Although promising in vitro and in preclinical studies, most clinical trials failed or yielded inconclusive results [27]. A notable exception is edaravone, a free radical scavenger used since 2001 in Asian countries 
(mostly Japan) for the treatment of acute ischemic stroke with or without recanalization treatments, which was shown to improve neurological deficit without significant adverse events [295]. Given its potent antioxidant effect, the molecule was also approved for the treatment of amyotrophic lateral sclerosis in 2017 [42,296]. The drug may be combined with other antioxidant and anti-inflammatory molecules to increase its efficacy. A combination of $30 \mathrm{mg}$ edaravone and $6 \mathrm{mg}$ of d-borneol, known as Y-2, is able to scavenge hydroxyl radicals, nitric oxide, and peroxynitrite and inhibit the expression of TNF- $\alpha$ and IL-1. Its efficacy in acute ischemic stroke is evaluated in a phase 3 multicenter, randomized, double-blind, placebo-controlled trial (NCT 04950920), which is currently enrolling 900 participants [268].

2. Statins, aside from their lipid-lowering effects, also exhibit anti-inflammatory properties by altering the release of interleukins and TNF- $\alpha$ [297] and inhibiting platelet NOX2, thromboxane A2, and platelet isoprostane formation. Larger strokes have been shown to be associated with lower levels of TNF- $\alpha$, IL-1 $\beta$, P-selectin, and ICAM-1 as compared to lacunar strokes [298]. Lovastatin and atorvastatin showed promising results in animal models of acute ischemic stroke, and a phase 4 clinical trial, NCT02225834, which enrolled 50 patients who received $80 \mathrm{mg}$ of Atorvastatin daily started within $48 \mathrm{~h}$ from stroke onset, demonstrated better clinical outcome in patients in the treatment arm [299]. In addition, chronic statin use before the ischemic event is associated with reduced stroke severity and improved functional outcome [300]. However, excessive and long-standing lowering of the low-density lipoprotein cholesterol fraction may be associated with cognitive decline [301].

3. Vinpocetine, a derivative of the alkaloid vincamine available in many countries as dietary supplement to enhance memory and cognition, reduces the release of proinflammatory cytokines and chemokines from microglia, endothelial cells, and vascular smooth muscle cells [302]. It can also antagonize atherosclerosis caused by a high-fat diet as well as injury-induced vascular remodeling [303]. Its effect in ischemic stroke was evaluated in a phase $2 / 3$ clinical trial (NCT 02878772), which enrolled 60 patients who were randomized to receive $30 \mathrm{mg}$ of vinpocetine daily for 14 consecutive days, starting within $48 \mathrm{~h}$ from stroke onset. The study is complete, but no results have yet been published [268].

4. RO27-3225, a melanocortin MC4 receptor agonist, reduces the expression of TNF$\alpha$, Bax, ERK, JNK, and caspase-3 and promotes improved functional recovery following ischemic stroke in gerbils [304].

5. Omega-3 polyunsaturated fatty acids prevent the release of cyclooxygenase 2 , hypoxia-inducible factor $1 \alpha$, and IL-1 $\beta$, as well as the activation of NOS, thereby having therapeutic potential in stroke [305].

6. Pharmacological inhibition or genetic deletion of COX-2 limits the production of proinflammatory prostanoids and diminishes BBB damage in acute cerebral ischemia [306], but blocking COX-2 later after the ischemic event impairs the endogenous repair mechanisms [307]. In addition, COX-2 inhibitors are associated with an increased risk of ischemic vascular events and increased stroke mortality if used before stroke onset [308].

7. TNF- $\alpha$ receptor inhibition with $\mathrm{R}-7050$ has recently been reported to decrease the activation of NF- $\mathrm{KB}$ and reduce levels of IL-6, thereby protecting against neurological deficits and edema in a rat model of permanent cerebral ischemia [309].

8. Inhibition of IL-1 $\beta$ receptor with recombinant human IL-1 receptor antagonist (IL$1 \mathrm{Ra}$, or anakinra) was tested in the SCIL-STROKE trial based on the promising results of a previous trial in subarachnoid hemorrhage. Although the drug was safe and well-tolerated, it did not significantly improve the outcome of ischemic stroke patients [153].

9. MicroRNAs, members of the small, noncoding RNA superfamily, have been much studied in recent years. They are single-stranded RNA molecules comprising 18-25 nucleotides which inhibit the expression of protein-coding genes by degrading or inhibiting the translation of target mRNA [310,311]. MicroRNA-124 (miR-124) has been shown to protect neurons after ischemia by regulating the expression of key genes [312], to modulate neuroinflammation [313], and, after being transferred from neurons to astrocytes, to regulate the expression of glutamate transporter 1 [314]. Intracerebroventricular delivery of miR-124-loaded nanoparticles (NPs) stimulated neuronal differentiation of the 
subventricular stem cells after oxygen and glucose deprivation [315]. However, biological simulants of miR-124 introduced into ischemic neural progenitor cells inhibited their proliferation [316]. As such, the therapeutic or detrimental role of miR-124 in ischemic stroke is still under research.

10. Transplantation of mesenchymal stem cells provides neuroprotection and immunomodulation and stimulates neurogenesis, astrogenesis, oligodendrogenesis, and angiogenesis, as well as the formation of new synapses [317]. They can be delivered intravenously [318], intra-arterially [319], or (in animal models) directly into the brain [320]. These cells then migrate into the damaged areas and differentiate into neurons and astroglial cells, also exhibiting paracrine activities, such as producing TGF- $\beta$ and inhibiting the secretion of MCP-1 and leukocyte infiltration [321], as well as producing IL-2 and IL-6 [322]. Extracellular vesicles derived from mesenchymal stromal cells are safer to use, carrying a lower risk of vessel blockage and vascular thrombosis, having lower immunogenicity, and being more able to cross the BBB [317], which allow systemic transplantation. They contain proteins, lipids, nucleic acids, and membrane receptors. The miRNAs contained and subsequently transferred to cells in the brain parenchyma can easily be subject to genetic modifications to induce neurogenesis and angiogenesis, modulate the immune response, and inhibit apoptosis [323]. This approach has made it to clinical trials, with 20 clinical trials having been already carried out or that are ongoing [317]. Several technical issues have to be solved relating to the optimal route of transplantation, the adequate number of cells, determining the right timing of administration from stroke onset, and the frequency of delivery [317]. However, from the studies conducted so far, the strategy appears safe, without significant side effects, allowing administration after days to weeks following stroke onset and leading to functional improvement [324]. As for extracellular vesicles, although promising results were obtained in preclinical studies, no clinical trial has yet been conducted, but a phase $1 / 2$ study with miR-124-enriched extracellular vesicles is listed as recruiting [268].

\subsection{Reasons for Discrepancies}

Many reasons for the discrepancies between preclinical and clinical trials can be discussed.

1. Most transient animal models of stroke use the mechanical artery occlusion, which causes thromboinflammation with subsequent microthrombosis, leading to brain injury. Clot-induced stroke models are less used, although they allow for determining the nature of the clot, whether platelet-rich or fibrin-rich [317]. Using these various models, it may well be that, for example, Tregs could target thromboinflammation and microthrombosis, thereby explaining the conflicting results of the studies performed. As such, immunomodulatory drugs should be evaluated in stroke models not associated with thromboinflammation.

2. In most animal models of transient arterial occlusion, complete occlusion is followed by complete reperfusion, a situation rarely achieved in human patients except for thrombectomized patients [20].

3. Many of the risk factors for stroke, such as smoking, age, alcohol consumption, stress, and age, cannot be adequately replicated in the laboratory, with most studies being performed on young animals. Moreover, although stroke predominates in aged women and inflammatory cells vary between genders, preclinical studies mainly use male animals [325].

4. One must not overlook the risk of infectious complications after stroke, which can significantly interfere with immunomodulatory drugs [326].

\section{Concluding Remarks}

Immunomodulatory therapy is a very appealing strategy for the treatment of acute ischemic stroke, both for patients treated with recanalization methods as well as for patients no longer eligible for reperfusion therapies. However, given the dual nature of neuroinflammation, further research is needed to establish the exact sequence and the stroke subtypes in which these strategies will yield positive results and lead to better functional outcomes. 
In our opinion, recanalization strategies will continue to be increasingly used for treating acute ischemic stroke, with extended therapeutic time windows through various methods (hypothermia, neuroprotectants) and a more careful selection of eligible patients (trying to identify the presence of penumbra through MRI techniques). Recanalization would be administered concomitantly with a cocktail of antioxidant molecules to diminish the magnitude of oxidative stress induced by reperfusion. In the subacute phase, neuroinflammatory pathways could be modulated to enhance the proliferation and migration of stem cells and improve recovery. From the studies performed so far, it appears that these strategies have an extended time window. It seems more plausible that using endogenous repair mechanisms, such as stem cell transplantation or genetically manipulated extracellular vesicle delivery, would have a better outcome than simply delivering exogenous molecules. To avoid rejection, autologous bone marrow cells could be harvested from the patient in the acute phase.

Author Contributions: A.J. conceived the review. A.J. and A.S. reviewed the literature and drafted the manuscript. A.J. revised the manuscript. All authors have read and agreed to the published version of the manuscript.

Funding: This research received no external funding.

Acknowledgments: The authors wish to thank the two anonymous reviewers for their valuable suggestions which helped improve the manuscript.

Conflicts of Interest: The authors declare no conflict of interest.

\section{References}

1. Katan, M.; Luft, A. Global burden of stroke. Semin. Neurol. 2018, 38, 208-211. [CrossRef] [PubMed]

2. Li, L.; Scott, C.A.; Rothwell, P.M.; on behalf of the Oxford Vascular Study. Trends in stroke incidence in high-income countries in the 21st century. Population-based study and systematic review. Stroke 2020, 51, 1372-1380. [CrossRef] [PubMed]

3. Danaei, G.; Finucane, M.M.; Lu, Y.; Singh, G.M.; Cowan, M.J.; Paciorek, C.J.; Lin, J.K.; Farzadfar, F.; Khang, Y.H.; Stevens, G.A.; et al. National, regional, and global trends in fasting plasma glucose and diabetes prevalence since 1980s: Systematic analysis of health examination surveys and epidemiological studies with 370 country-years and 2.7 million participants. Lancet 2011, 378, 31-40. [CrossRef]

4. NCD Risk Factor Collaboration (NCD-RisC). Trends in adult body mass index in 200 countries from 1975 to 2014 : A pooled analysis of 1698 population-based measurement studies with 19.2 million participants. Lancet 2016, 387, 1377-1396. [CrossRef]

5. Hacke, W.; Kaste, M.; Bluhmki, E.; Brozman, M.; Dávalos, A.; Guidetti, D.; Larrue, V.; Lees, K.R.; Medeghri, Z.; Machnig, T.; et al. Thrombolysis with alteplase 3 to $4.5 \mathrm{~h}$ after acute ischemic stroke. N. Engl. J. Med. 2008, 359, 1317-1329. [CrossRef]

6. Smith, W.S.; Sung, G.; Starkman, S.; Saver, J.L.; Kidwell, C.S.; Gobin, Y.P.; Lutsep, H.L.; Nesbit, G.M.; Grobelny, T.; Rymer, M.M.; et al. Safety and efficacy of mechanical embolectomy in acute ischemic stroke: Results of the MERCI trial. Stroke 2005, 36, 1432-1438. [CrossRef]

7. Nogueira, R.G.; Jadhav, A.P.; Haussen, D.C.; Bonafe, A.; Budzik, R.F.; Bhuva, P.; Yavagal, D.R.; Ribo, M.; Cognard, C.; Hanel, R.A.; et al. Thrombectomy 6 to $24 \mathrm{~h}$ after stroke with a mismatch between deficit and infarct. N. Engl. J. Med. 2018, 378, 11-21. [CrossRef]

8. Powers, W.J.; Rabinstein, A.A.; Ackerson, T.; Adeoye, O.M.; Bambakidis, M.C.; Becker, K.; Biller, J.; Brown, M.; Demaerschalk, D.M.; Hoh, B.; et al. Guidelines for the early management of patients with acute ischemic stroke: 2019 update to the 2018 guidelines for the early management of patients with acute ischemic stroke: A guideline for healthcare professionals from the American Heart Association/American Stroke Association. Stroke 2019, 50, e344-e418. [PubMed]

9. Jurcau, A.; Ardelean, I.A. Molecular pathophysiological mechanisms of ischemia/reperfusion injuries after recanalization therapy for acute ischemic stroke. J. Integr. Neurosci. 2021, 20, 727-744.

10. Lin, L.; Wang, X.; Yu, Z. Ischemia-reperfusion injury in the brain: Mechanisms and potential therapeutic strategies. Biochem. Pharmacol. 2016, 5, 213.

11. Wong, C.H.Y.; Crack, P.J. Modulation of neuroinflammation and vascular response by oxidative stress following cerebral ischemia-reperfusion injury. Curr. Med. Chem. 2008, 15, 1-14. [PubMed]

12. Xiong, X.Y.; Liu, L.; Yang, Q.W. Refocusing neuroprotection in cerebral reperfusion era: New challenges and strategies. Front. Neurol. 2018, 9, 249. [CrossRef] [PubMed]

13. $\mathrm{Wu}, \mathrm{L} . ;$ Xiong, X.; Wu, X.; Ye, Y.; Jian, Z.; Zhi, Z.; Gu, L. Targeting oxidative stress and inflammation to prevent ischemiareperfusion injury. Front. Mol. Neurosci. 2020, 13, 28. [CrossRef]

14. Chamorro, A.; Hallenbeck, J. The harms and benefits of inflammatory and immune responses in vascular disease. Stroke 2006, 37, 291-293. [CrossRef] 
15. Enzmann, G.; Kargaran, S.; Engelhardt, B. Ischemia-reperfusion injury in stroke: Impact of the brain barriers and brain immune privilege on neutrophil function. Ther. Adv. Neurol. Disord. 2018, 11, 1-15. [CrossRef] [PubMed]

16. Armulik, A.; Genové, G.; Mäe, M.; Nisancioglu, M.H.; Wallgard, E.; Niaudet, C.; He, L.; Norlin, J.; Lindblom, P.; Strittmatter, K.; et al. Pericytes regulate the blood brain barrier. Nature 2010, 468, 557-561. [CrossRef]

17. Abbott, N.J.; Patabendige, A.A.; Dolman, D.E.; Yusof, S.R.; Begley, D.J. Structure and function of the blood brain barrier. Neurobiol. Dis. 2010, 37, 13-25. [CrossRef] [PubMed]

18. Anrather, J.; Iadecola, C. Inflammation and stroke: An overview. Neurotherapeutics 2016, 13, 661-670. [CrossRef]

19. Tahsili-Fahadan, P.; Farrokh, S.; Geocadin, R.G. Hypothermia and brain inflammation after cardiac arrest. Brain Circ. 2018, 4, 1-13.

20. Drieu, A.; Levard, D.; Vivien, D.; Rubio, M. Anti-inflammatory treatments for stroke: From bench to bedside. Ther. Adv. Neurol. Dis. 2018, 11, 1-15. [CrossRef] [PubMed]

21. De Meyer, S.F.; Denorme, F.; Langhauser, F.; Geuss, E.; Fluri, F.; Kleinschnitz, C. Thromboinflammation in stroke brain damage. Stroke 2016, 47, 1165-1172. [CrossRef]

22. Palabrica, T.; Lobb, F.; Furei, B.C.; Aronovitz, M.; Benjamin, C.; Hsu, Y.M.; Sajer, S.A.; Furie, B. Leukocyte accumulation promoting fibrin deposition is mediated in vivo by P-selectin on adherent platelets. Nature 1992, 359, 848-851. [CrossRef]

23. Rezaie, A.R. Protease-activated receptor signaling by coagulation proteases in endothelial cells. Thromb. Haemost. 2014, 112, 876-882. [PubMed]

24. Turovsky, E.A.; Zinchenko, V.P.; Gaidin, S.G.; Turovskaya, M.V. Calcium-binding proteins protect GABAergic neurons of the hippocampus from hypoxia and ischemia in vitro. Biochemistry 2018, 12, 74-84. [CrossRef]

25. Turovsky, E.A.; Varlamova, E.G.; Plotnikov, E.Y. Mechanisms underlying the protective effect of the peroxiredoxin-6 are mediated via the protection of astrocytes during ischemia/reoxygenation. Int. J. Mol. Sci. 2021, 22, 8805. [CrossRef] [PubMed]

26. Kalogeris, T.; Baines, C.P.; Krenz, M.; Korthius, R.J. Cell biology of ischemia/reperfusion injury. Int. Rev. Cell Mol. Biol. 2012, 298, 229-317.

27. Simion, A.; Jurcau, A. The role of antioxidant treatment in acute ischemic stroke: Past present and future. Neurol. Res. Surg. 2019, 2, 1-7. [CrossRef]

28. Jayaraj, R.L.; Azimullah, S.; Beiram, R.; Jala, F.Y.; Rosenberg, G.A. Neuroinflammation: Friend and foe for ischemic stroke. J. Neuroinflamm. 2019, 16, 142. [CrossRef]

29. Alliot, F.; Godin, I.; Pessac, B. Microglia derived from progenitors, originating from the yolk sac, and which proliferate in the brain. Brain Res. Dev. Brain Res. 1999, 117, 145-152. [CrossRef]

30. Kanazawa, M.; Ninomiya, I.; Hatakeyama, M.; Takahashi, T.; Shimohata, T. Microglia and monocytes/macrophages polarization reveal novel therapeutic mechanism against stroke. Int. J. Mol. Sci. 2017, 18, 2135. [CrossRef] [PubMed]

31. Jin, R.; Yang, G.; Li, G. Inflammatory mechanisms in ischemic stroke: Role of inflammatory cells. J. Leukoc. Biol. 2010, 87, 779-789. [CrossRef]

32. Nimmerjahn, A.; Kirchhoff, F.; Helmchen, F. Resting microglial cells are highly dynamic surveillants of brain parenchyma in vivo. Science 2005, 308, 1314-1318. [CrossRef] [PubMed]

33. Kierdorf, K.; Prinz, M. Factors regulating microglia activation. Front. Cell. Neurosci. 2013, 7, 44. [CrossRef]

34. Pocock, J.M.; Kettenmann, H. Neurotransmitter receptors on microglia. Trends Neurosci. 2007, 30, 527-535. [CrossRef] [PubMed]

35. Hoek, R.M.; Ruuls, S.R.; Murphy, C.A.; Wright, G.J.; Goddard, R.; Zurawski, S.M.; Blom, B.; Homola, M.E.; Streit, W.J.; Brown, M.H.; et al. Down-regulation of the macrophage lineage through interaction with OX2 (CD200). Science 2000, 290, 1768-1771. [CrossRef]

36. Sunnemark, D.; Eltayeb, S.; Nilsson, M.; Wallstrom, E.; Lassmann, H.; Olsson, T.; Berg, A.-L.; Ericsson-Dahlstrand, A. CX3CL1 (fractalkine) and CX3CR1 expression in myelin oligodendrocyte glycoprotein-induced experimental autoimmune encephalomyelitis: Kinetics and cellular origin. J. Neuroinflam. 2005, 2, 17. [CrossRef] [PubMed]

37. Guruswamy, R.; ElAli, A. Complex roles of microglial cells in ischemic stroke pathobiology: New insights and future directions. Int. J. Mol. Sci. 2017, 18, 496. [CrossRef]

38. ElAli, A.; Rivest, S. Microglia ontology and signaling. Front. Cell Dev. Biol. 2016, 4, 72. [CrossRef]

39. Ito, D.; Tanaka, K.; Suzuki, S.; Dembo, T.; Fukuuchi, Y. Enhanced expression of Iba1, ionized calcium-binding adapter molecule 1, after transient focal cerebral ischemia in rat brain. Stroke 2001, 32, 1208-1215. [CrossRef] [PubMed]

40. Orihuela, R.; McPherson, C.A.; Harry, G.J. Microglial M1/M2 polarization and metabolic states. Br. J. Pharmacol. 2016, 173, 649-665. [CrossRef]

41. Fernandez-Lizarbe, S.; Pascual, M.; Guerri, C. Critical role of TLR4 response in the activation of microglia by ethanol. J. Immunol. 2009, 183, 4733-4744. [CrossRef] [PubMed]

42. Jurcau, A. Insights into the pathogenesis of neurodegenerative diseases: Focus on mitochondrial dysfunction and oxidative stress. Int. J. Mol. Sci. 2021, 22, 11847. [CrossRef]

43. Weinstein, J.R.; Koerner, I.P.; Möller, T. Microglia in ischemic brain injury. Future Neurol. 2011, 5, 227-246. [CrossRef]

44. Ridder, D.A.; Schwaninger, M. NF-kappaB signaling in cerebral ischemia. Neuroscience 2009, 158, 995-1006. [CrossRef]

45. Xu, H.; Qin, W.; Hu, X.; Mu, S.; Zhu, J.; Lu, W.; Luo, Y. Lentivirus-mediated overexpression of OTULIN ameliorates microglia activation and neuroinflammation by depressing the activation of the NF- $\kappa B$ signaling pathway in cerebral ischemia/reperfusion rats. J. Neuroinflamm. 2018, 15, 83. [CrossRef] 
46. Cardona, A.E.; Pioro, E.P.; Sasse, M.E.; Kostenko, V.; Cardona, S.M.; Dijkstra, I.M.; Huang, D.; Kidd, G.; Dombrovski, S.; Dutta, R.; et al. Control of microglial neurotoxicity by the fractalkine receptor. Nat. Neurosci. 2006, 9, 917-924. [CrossRef] [PubMed]

47. Anttila, J.E.; Whitaker, K.W.; Wires, E.S.; Harvey, B.K.; Airavaara, M. Role of microglia in ischemic focal stroke and recovery: Focus on toll-like receptors. Prog. Neuro-Psychopharmacol. Biol. Psychiatry 2017, 79, 3-14. [CrossRef]

48. Prinz, M.; Priller, J. Microglia and brain macrophages in the molecular age: From origin to neuropsychiatric disease. Nat. Rev. Neurosci. 2014, 15, 300-312. [CrossRef]

49. Almolda, B.; de Labra, C.; Barrera, I.; Gruart, A.; Delgado-Garcia, J.M.; Villacampa, N.; Vilella, A.; Hofer, M.J.; Hidalgo, J.; Campbell, I.L.; et al. Alterations in microglial phenotype and hippocampal neuronal function in transgenic mice with astrocytetargeted production of interleukin-10. Brain Behav. Immun. 2015, 45, 80-97. [CrossRef] [PubMed]

50. Gordon, S. Alternative activation of macrophages. Nat. Rev. Immunol. 2003, 3, 23-35. [CrossRef] [PubMed]

51. Mills, C.D. M1and M2 macrophages: Oracles of health and disease. Crit. Rev. Immunol. 2012, 32, 463-488. [CrossRef]

52. Martinez, F.O.; Sica, A.; Mantovani, A.; Locati, M. Macrophage activation and polarization. Front. Biosci. 2008, $13,453-461$. [CrossRef]

53. Roca, H.; Varsos, Z.S.; Sud, S.; Craig, M.J.; Ying, C.; Pienta, K.J. CCL2 and interleukin-6 promote survival of human CD11b+ peripheral blood mononuclear cells and induce M2-type macrophage polarization. J. Biol. Chem. 2009, 284, 34342-34354. [CrossRef]

54. Gleissner, C.A.; Shaked, I.; Little, K.M.; Ley, K. CXC chemokine ligand 4 induces a unique transcriptome in monocyte-derived macrophages. J. Immunol. 2010, 184, 4810-4818. [CrossRef]

55. Hu, X.; Li, P.; Guo, Y.; Wang, H.; Leak, R.K.; Chen, S.; Gao, Y.; Chen, J. Microglia/macrophage polarization dynamics reveal novel mechanism of injury expansion after focal cerebral ischemia. Stroke 2012, 43, 3063-3070. [CrossRef] [PubMed]

56. Tang, Y.; Le, W. Differential roles of M1 and M2 microglia in neurodegenerative diseases. Mol. Neurobiol. 2016, 53, 1181-1194. [CrossRef] [PubMed]

57. Perego, C.; Fumagalli, S.; De Simoni, M.-G. Temporal pattern of expression and colocalization of microglia/macrophage phenotype markers following brain ischemic injury in mice. J. Neuroinflamm. 2011, 8, 174. [CrossRef]

58. West, A.P.; Brodsky, I.E.; Rahner, C.; Woo, D.K.; Erdjument-Bromage, H.; Tempst, P.; Walsh, M.C.; Choi, Y.; Shadel, G.S.; Ghosh, S. TLR signaling augments macrophage bactericidal activity through mitochondrial ROS. Nature 2011, 472, 476-480. [CrossRef] [PubMed]

59. Lai, A.; Todd, K.G. Microglia in cerebral ischemia: Molecular actions and interactions. Can. J. Physiol. Pharmacol. 2006, 84, 49-59. [CrossRef]

60. Ortega-Gómez, A.; Perretti, M.; Soehnlein, O. Resolution of inflammation: An integrated view. EMBO Mol. Med. 2013, 5, 661-674. [CrossRef]

61. Sica, A.; Mantovani, A. Macrophage plasticity and polarization: In vivo veritas. J. Clin. Invest. 2012, 122, 787-795. [CrossRef]

62. Kigerl, K.A.; Gensel, J.C.; Ankeny, D.P.; Alexander, J.K.; Donnelly, D.J.; Popovich, P.G. Identification of two distinct macrophage subsets with divergent effects causing either neurotoxicity or regeneration in the injured mouse spinal cord. J. Neurosci. 2009, 29, 13435-13444. [CrossRef]

63. Lee, E.J.; Moon, P.G.; Baek, M.C.; Kim, H.S. Comparison of the effects of matrix metalloproteinase inhibitors on TNF- $\alpha$ release from activated microglia and TNF- $\alpha$ converting enzyme activity. Biomol. Ther. 2014, 22, 414-419. [CrossRef]

64. Lisi, L.; Stigliano, E.; Lauriola, L.; Navarra, P.; Dello Russo, C. Proinflammatory-activated glioma cells induce a switch in microglial polarization and activation status, from a predominant M2b phenotype to a mixture of M1 and M2a/B polarized cells. ASN Neuro 2014, 6, 171-183. [CrossRef] [PubMed]

65. Crain, J.M.; Nikodemova, M.; Watters, J.J. Microglia express distinct M1 and M2 phenotypic markers in the postnatal and adult central nervous system in male and female mice. J. Neurosci. Res. 2013, 91, 1143-1151. [CrossRef]

66. Locatelli, G.; Theodorou, D.; Kendirli, A.; Jordao, M.J.C.; Stazewski, O.; Phulphagar, K.; Cantuti-Castelvetri, L.; Dagkalis, A.; Bessis, A.; Simons, M.; et al. Mononuclear phagocytes locally specify and adapt their phenotype in a multiple sclerosis model. Nat. Neurosci. 2018, 21, 1196-1208. [CrossRef]

67. Fang, M.; Zhong, L.; Jin, X.; Cui, R.; Yang, W.; Gao, S.; Lv, J.; Li, B.; Liu, T. Effect of inflammation on the process of stroke rehabilitation and poststroke depression. Front. Psychiatry 2019, 10, 184. [CrossRef] [PubMed]

68. Gelderblom, M.; Leypoldt, F.; Steinbach, K.; Behrens, D.; Choe, C.-U.; Siler, D.A.; Arumugam, T.V.; Orthey, E.; Gerloff, C.; Tolosa, E.; et al. Temporal and spatial dynamics of cerebral immune cell accumulation in stroke. Stroke 2009, 40, 1849-1857. [CrossRef] [PubMed]

69. Emmrich, J.V.; Ejaz, S.; Neher, J.J.; Williamson, D.J.; Baron, J.C. Regional distribution of selective neuronal loss and microglial activation across the MCA territory after transient focal ischemia: Quantitative versus semiquantitative systematic immunohistochemical assessment. J. Cereb. Blood Flow Metab. 2015, 35, 20-27. [CrossRef]

70. Denes, A.; Vidyasagar, R.; Feng, J.; Narvainen, J.; McColl, B.W.; Kauppinen, R.A.; Allan, S.M. Proliferating resident microglia after focal cerebral ischemia in mice. J. Cereb. Blood Flow Metab. 2007, 27, 1941-1953. [CrossRef]

71. Ma, M.W.; Wang, J.; Zhang, Q.; Wang, R.; Dhandapani, K.M.; Vadlamudi, R.K.; Brann, D.W. NADPH oxidase in brain injury and neurodegenerative disorders. Mol. Neurodegener. 2017, 12, 7. [CrossRef] [PubMed]

72. Zhou, M.; Wang, C.M.; Yang, W.L.; Wang, P. Microglial CD14 activated by iNOS contributes to neuroinflammation in cerebral ischemia. Brain Res. 2013, 1506, 105-114. [CrossRef] [PubMed] 
73. Facci, L.; Barbierato, M.; Marinelli, C.; Argentini, C.; Skaper, S.D.; Giusti, P. Toll-like receptors 2, -3 and -4 prime microglia but not astrocytes across the central nervous system regions for ATP-dependent interleukin-1 $\beta$ release. Sci. Rep. 2014, 4, 6824. [CrossRef] [PubMed]

74. Hua, F.; Ma, J.; Ha, T.; Xia, Y.; Kelley, J.; Williams, D.L.; Kao, R.L.; Browder, I.W.; Schweitzer, J.B.; Kalbfleisch, J.H.; et al. Activation of toll-like receptor 4 signaling contributes to hippocampal neuronal death following global cerebral ischemia/reperfusion. J. Neuroimmunol. 2007, 190, 101-111. [CrossRef]

75. Sun, M.; Deng, B.; Zhao, X.; Gao, C.; Yang, L.; Zhao, H.; Yu, D.; Zhang, F.; Xu, L.; Chen, L.; et al. Isoflurane preconditioning provides neuroprotection against stroke by regulating the expression of the TLR4 signaling pathway to alleviate microglial activation. Sci. Rep. 2015, 5, 1445.

76. Lalancette-Hebert, M.; Gowing, G.; Simard, A.; Weng, Y.C.; Kriz, J. Selective ablation of proliferating microglial cells exacerbates ischemic injury in the brain. J. Neurosci. 2007, 27, 2596-2605. [CrossRef]

77. Kitamura, Y.; Takata, K.; Inden, M.; Tsuchiya, D.; Yanagisawa, D.; Nakata, J.; Taniguchi, T. Intracerebroventricular injection of microglia protects against focal brain ischemia. J. Pharmacol. Sci. 2004, 94, 203-206. [CrossRef]

78. Krupinski, J.; Kaluza, J.; Kumar, P.; Kumar, S. Immunocytochemical studies of cellular reaction in human ischemic brain stroke. MAB anti-CD68 stains macrophages, astrocytes and microglial cells in infarcted area. Folia Neuropathol. 1996, $34,17-24$.

79. Price, C.J.; Wang, D.; Menon, D.K.; Guadagno, J.V.; Cleij, M.; Fryer, T.; Aigbirhio, F.; Baron, J.-C.; Warburton, E.A. Intrinsic activated microglia map to the peri-infarct zone in the subacute phase of ischemic stroke. Stroke 2006, 37, 1749-1753. [CrossRef]

80. Pappata, S.; Levasseur, M.; Gunn, R.N.; Myers, R.; Crouzel, C.; Syrota, A.; Jones, T.; Kreutzberg, G.W.; Banati, R.B. Thalamic microglial activation in ischemic stroke detected in vivo by PET and 11c 1195. Neurology 2000, 55, 1052-1054. [CrossRef]

81. Dugue, R.; Dugue, A.; Barone, F.C. Roles of pro- and anti-inflammatory cytokines in traumatic brain injury and acute ischemic stroke. In Mechanisms of Neuroinflammation; Abreu, G.E.A., Ed.; IntechOpen: Rijeka, Croatia, 2017; pp. $211-261$.

82. Singhal, G.; Baune, B.T. Microglia: An interface between the loss of neuroplasticity and depression. Front. Cell. Neurosci. 2017, 11, 270. [CrossRef]

83. Bylicky, M.; Mueller, G.P.; Day, R.M. Mechanisms of endogenous neuroprotective effects of astrocytes in brain injury. Oxid. Med. Cell. Longev. 2018, 2018, 6501031. [CrossRef] [PubMed]

84. Ketheeswaranathan, P.; Turner, N.A.; Spary, E.J.; Batten, T.F.; McColl, B.W.; Saha, S. Changes in glutamate transporter expression in mouse forebrain areas following focal ischemia. Brain Res. 2011, 1418, 93-103. [CrossRef]

85. Maida, C.D.; Norrito, R.L.; Daidone, M.; Tuttolomomdo, A.; Pinto, A. Neuroinflammatory mechanisms in ischemic stroke: Focus on cardioembolic stroke, background, and therapeutic approaches. Int. J. Mol. Sci. 2020, 21, 6454. [CrossRef]

86. Wang, H.; Song, G.; Chuang, H.; Chiu, C.; Abdelmaksoud, A.; Ye, Y.; Zhao, L. Portrait of glial scar in neurological diseases. Int. J. Immunopathol. Pharmacol. 2018, 31, 1-6. [CrossRef] [PubMed]

87. Rempe, R.G.; Hartz, A.M.; Bauer, B. Matrix metalloproteinases in the brain and blood-brain barrier: Versatile breakers and makers. Br. J. Pharmacol. 2016, 36, 1481-1507. [CrossRef]

88. Nowicka, D.; Rogozinska, K.; Aleksy, M.; Witte, O.W.; Skangiel-Kramska, J. Spatiotemporal dynamics of astroglial and microglial responses after photothrombotic stroke in the rat brain. Acta Neurobiol. Exp. 2008, 68, 155.

89. Li, M.; Li, Z.; Yao, Y.; Jin, W.-N.; Wood, K.; Liu, Q.; Shi, F.; Hao, J. Astrocyte-derived interleukin-15 exacerbates ischemic brain injury via propagation of cellular immunity. Proc. Natl. Acad. Sci. USA 2017, 114, 396-405. [CrossRef]

90. Pawluk, H.; Woźniak, A.; Grześk, G.; Kolodjieska, R.; Kozakiewicz, M.; Kopkowska, E.; Grzechowiak, E.; Kozera, G. The role of pro-inflammatory cytokines in the pathogenesis of ischemic stroke. Clin. Interv. Aging 2020, 15, 469-484. [CrossRef] [PubMed]

91. Pan, J.; Konstas, A.-A.; Bateman, B.; Ortolano, G.A.; Pile-Spellman, J. Reperfusion injury following cerebral ischemia: Pathophysiology, MR imaging, and potential therapies. Neuroradiology 2007, 49, 93-102. [CrossRef]

92. Jean, W.C.; Spellman, S.R.; Nussbaum, E.S.; Low, W.C. Reperfusion injury after focal cerebral ischemia: The role of inflammation and the therapeutic horizon. Neurosurgery 1998, 43, 1382-1396. [CrossRef]

93. Nourshargh, S.; Krombach, F.; Dejana, E. The role of JAM-A and PECAM-1 in modulating leucocyte infiltration in inflamed ischemic tissues. J. Leukoc. Biol. 2006, 80, 714-718. [CrossRef]

94. Nourshargh, S.; Hordjik, P.L.; Sixt, M. Breaching multiple barriers: Leukocyte motility through venular walls and the interstitium. Nat. Rev. Mol. Cell Biol. 2010, 11, 366-378. [CrossRef]

95. Rodriguez, S.F.; Granger, D.N. Role of blood cells in ischemia-reperfusion-induced endothelial barrier failure. Cardiovasc. Res. 2010, 87, 291-299. [CrossRef] [PubMed]

96. Collard, C.D.; Gelman, S. Pathophysiology, clinical manifestations, and prevention of ischemia-reperfusion injury. Anesthesiology 2001, 94, 1133-1138. [CrossRef]

97. Del Zoppo, G.J. Acute anti-inflammatory approaches to ischemic stroke. Ann. N. Y. Acad. Sci. 2010, 1207, 143-148. [CrossRef]

98. Pluta, R.; Januszewski, S.; Czuczwar, S.J. Neuroinflammation in post-ischemic neurodegeneration of the brain: Friend, foe, or both? Int. J. Mol. Sci. 2021, 22, 4405. [CrossRef] [PubMed]

99. Kim, J.Y.; Park, J.; Chang, J.Y.; Kim, S.H.; Lee, J.E. Inflammation after ischemic stroke: The role of leukocytes and glial cells. Exp. Neurobiol. 2016, 25, 241-251. [CrossRef]

100. Yoshimura, A.; Ito, M. Resolution of inflammation and repair after ischemic brain injury. Neuroimmunol. Neuroinflammation 2020, 7, 264-276. [CrossRef] 
101. Tanaka, R.; Komine-Kobayashi, M.; Mochizuki, H.; Yamada, M.; Furuya, T.; Migita, M.; Shimada, T.; Mizuno, Y.; Urabe, T. Migration of enhanced green fluorescent protein expressing bone marrow-derived microglia/macrophage into the mouse brain following permanent focal ischemia. Neuroscience 2003, 117, 531-539. [CrossRef]

102. Jickling, G.C.; Liu, D.; Ander, B.P.; Stamova, B.; Zhan, X.; Sharp, F.R. Targeting neutrophils in ischemic stroke: Translocation insights from experimental studies. J. Cereb. Blood Flow Metab. 2015, 35, 888-901. [CrossRef] [PubMed]

103. Kleinschnitz, C.; Schwab, N.; Kraft, P.; Hagedorn, I.; Dreykluft, A.; Schwarz, T.; Austinat, M.; Niewandt, B.; Windl, H.; Stoll, G. Early detrimental T-cell effects in experimental cerebral ischemia are neither related to adaptive immunity nor thrombus formation. Blood 2010, 115, 3835-3842. [CrossRef]

104. Shichita, T.; Sugiyama, Y.; Ooboshi, H.; Sugimori, H.; Nakagawa, R.; Takada, I.; Iwaki, T.; Okada, Y.; Iida, M.; Cua, D.J.; et al. Pivotal role of cerebral interleukin-17-producing $\gamma \delta \mathrm{T}$ cells in the delayed phase of ischemic brain injury. Nat. Med. 2009, 15, 946-950. [CrossRef]

105. Brait, V.H.; Arumugam, T.V.; Drummond, G.R.; Sobey, C.G. Importance of T lymphocytes in brain injury, immunodeficiency, and recovery after cerebral ischemia. J. Cereb. Blood Flow Metab. 2012, 32, 598-611. [CrossRef]

106. Wang, H.; Wang, Z.; Wu, Q.; Yuan, Y.; Cao, W.; Zhang, X. Regulatory T cells in ischemic stroke. CNS Neurosci. Ther. 2021, 27, 643-651. [CrossRef] [PubMed]

107. Hori, S.; Nomura, T.; Sakaguchi, S. Control of regulatory T cell development by the transcription factor Foxp3. Science 2003, 299, 1057-1061. [CrossRef]

108. Planas, A.M.; Chamorro, A. Regulatory T cells protect the brain after stroke. Nat. Med. 2009, 15, 192-199. [CrossRef]

109. Hu, X.; Li, P.; Chen, J. PRO: Regulatory T cells are protective in ischemic stroke. Stroke 2013, 44, e85-e86. [CrossRef] [PubMed]

110. Llovera, G.; Benakis, C.; Enzmann, G.; Cai, R.; Arzberger, T.; Ghasemigharagoz, A.; Mao, X.; Malik, R.; Lazarevic, I.; Liebscher, S.; et al. The choroid plexus is a key cerebral invasion route for T cells after stroke. Acta Neuropathol. 2017, 134, 851-868. [CrossRef]

111. Li, P.; Gan, Y.; Sun, B.L.; Zhang, F.; Lu, B.; Gao, Y.; Liang, W.; Thomson, A.W.; Chen, J.; Hu, X. Adoptive regulatory T-cell therapy protects against cerebral ischemia. Ann. Neurol. 2013, 74, 458-471. [CrossRef] [PubMed]

112. Park, K.P.; Rosell, A.; Foerch, C.; Xing, C.; Kim, W.J.; Lee, S.; Opdenakker, G.; Furie, K.L.; Lo, E.H. Plasma and brain matrix metalloproteinase-9 after acute focal cerebral ischemia in rats. Stroke 2009, 40, 2836-2842. [CrossRef]

113. Liesz, A.; Hu, X.; Kleinschnitz, C.; Offner, H. Functional role of regulatory lymphocytes in stroke: Facts and controversies. Stroke 2015, 46, 1422-1430. [CrossRef] [PubMed]

114. Kleinschnitz, C.; Kraft, P.; Dreykluft, A.; Hagedorn, I.; Göbel, K.; Schuhmann, M.K.; Langhauser, F.; Helluy, X.; Schwarz, T.; Bittner, S.; et al. Regulatory T cells are strong promoters of acute ischemic stroke in mice by inducing dysfunction of the cerebral microvasculature. Blood 2013, 121, 679-691. [CrossRef] [PubMed]

115. Xie, L.; Choudhury, G.R.; Winters, A.; Yang, S.H.; Jin, K. Cerebral regulatory T cells restrain microglia/macrophage-mediated inflammatory response via IL-10. Eur. J. Immunol. 2015, 45, 180-191. [CrossRef]

116. Ito, M.; Komai, K.; Mise-Omata, S.; Iizuka-Koga, M.; Noguchi, Y.; Kondo, T.; Sakai, R.; Matsuo, K.; Nakayama, T.; Yoshie, O.; et al. Brain regulatory $\mathrm{T}$ cells suppress astrogliosis and potentiate neurological recovery. Nature 2019, 565, 246-250. [CrossRef]

117. Ruan, L.; Lau, B.W.; Wang, J.; Huang, L.; Zhuge, Q.; Wang, B.; Jin, K.; So, K.-F. Neurogenesis in neurological and psychiatric diseases and brain injury: From bench to bedside. Prog. Neurobiol. 2014, 115, 116-137. [CrossRef]

118. Kalogeris, T.; Baines, C.P.; Krenz, M.; Korthuis, R.J. Ischemia/reperfusion. Compr. Physiol. 2016, 7, 113-170.

119. Shaik, N.F.; Regan, R.F.; Naik, U.P. Platelets as drivers of ischemia/reperfusion injury after stroke. Blood Adv. 2021, 5, 1576-1584. [CrossRef] [PubMed]

120. Bladowski, M.; Gawrys, J.; Gajecki, D.; Szahidewicz-Krupska, E.; Sawicz-Bladowska, A.; Doroszko, A. Role of the platelets and nitric oxide biotransformation in ischemic stroke: A translative review from bench to bedside. Oxid. Med. Cell Longev. 2020, 2020, 2979260. [CrossRef]

121. Wang, G.R.; Zhu, Y.; Halushka, P.V.; Lincoln, T.M.; Mendelsohn, M.E. Mechanism of platelet inhibition by nitric oxide: In vivo phosphorylation of thromboxane receptor by cyclic GMP-dependent protein kinase. Proc. Natl. Acad. Sci. USA 1998, 95, $4888-4893$. [CrossRef]

122. Zhu, J.; Song, W.; Li, L.; Fan, X. Endothelial nitric oxide synthase: A potential therapeutic target for cerebrovascular diseases. Mol. Brain 2016, 9, 30. [CrossRef]

123. Kuo, M.C.; Patschan, D.; Patschan, S.; Cohen-Gould, L.; Park, H.-C.; Ni, J.; Addabbo, F.; Goligorsky, M.S. Ischemia-induced exocytosis of Weibel-Palade bodies mobilizes stem cells. J. Am. Soc. Nephrol. 2008, 19, 2321-2330. [CrossRef]

124. Zhao, B.Q.; Chauhan, A.K.; Canault, M.; Patten, I.S.; Yang, J.J.; Dockal, M.; Scheiflinger, S.; Wagner, D.D. von Willebrand factor-cleaving protease ADAMTS13 reduces ischemic brain injury in experimental stroke. Blood 2009, 114, 3329-3334. [CrossRef]

125. Fujioka, M.; Hayakawa, K.; Mishima, K.; Kunizawa, A.; Irie, K.; Higuchi, S.; Nakano, T.; Muroi, C.; Fukushima, H.; Sugimoto, M.; et al. ADAMTS13 gene deletion aggravates ischemic brain damage: A possible neuroprotective role of ADAMTS13 by ameliorating postischemic hypoperfusion. Blood 2010, 115, 1650-1653. [CrossRef]

126. Page, C.; Pitchford, S. Neutrophil and platelet complexes and their relevance to neutrophil recruitment and activation. Int. Immunopharmacol. 2013, 17, 1176-1184. [CrossRef] [PubMed]

127. Litt, M.R.; Jeremy, R.W.; Weisman, H.F.; Winkelstein, J.A.; Becker, L.C. Neutrophil depletion limited to reperfusion reduces myocardial infarct size after 90 min of ischemia. Evidence for neutrophil-mediated reperfusion injury. Circulation 2011, 123, 2579-2590. 
128. Ishikawa, M.; Cooper, D.; Arumugam, T.V.; Zhang, J.H.; Nanda, A.; Granger, D.N. Platelet-leukocyte-endothelial cell interactions after middle cerebral artery occlusion and reperfusion. J. Cereb. Blood Flow Metab. 2004, 24, 907-915. [CrossRef] [PubMed]

129. Franks, Z.G.; Campbell, R.A.; Weyrich, A.S.; Rondina, M.T. Platelet-leukocyte interactions link inflammatory and thromboembolic events in ischemic stroke. Ann. N. Y. Acad. Sci. 2010, 1207, 11-17. [CrossRef]

130. Vogel, S.; Bodenstein, R.; Chen, Q.; Feil, S.; Feil, R.; Rheinlaender, J.; Schäffer, T.E.; Bohn, E.; Frick, J.S.; Borst, O.; et al. Plateletderived HMGB1 is a critical mediator of thrombosis. J. Clin. Invest. 2015, 125, 4638-4654. [CrossRef] [PubMed]

131. Nishigaya, K.; Yoshida, Y.; Sasuga, M.; Nukui, H.; Ooneda, G. Effect of recirculation on exacerbation of ischemic vascular lesions in rat brain. Stroke 1991, 22, 635-642. [CrossRef]

132. Sreeramkumar, V.; Adrover, J.M.; Ballesteros, I.; Cuartero, M.I.; Rossaint, J.; Bilbao, I.; Nácher, M.; Pitaval, C.; Radovanovic, I.; Fukui, Y.; et al. Neutrophils scan for activated platelets to initiate inflammation. Science 2014, 346, 1234-1238. [CrossRef]

133. Fujii, T.; Sakata, A.; Nishimura, S.; Eto, K.; Nagata, S. TMEM16F is required for phosphatidylserine exposure and microparticle release in activated mouse platelets. Proc. Natl. Acad. Sci. USA 2015, 112, 12800-12805. [CrossRef]

134. Deppermann, C.; Kraft, P.; Volz, J.; Schuhmann, M.K.; Beck, S.; Wolf, K.; Stegner, D.; Stoll, G.; Nieswandt, B. Platelet secretion is crucial to prevent bleeding in the ischemic brain but not in the inflamed skin or lung in mice. Blood 2017, 129, $1702-1706$. [CrossRef]

135. Kleinschnitz, C.; Pozgajova, M.; Pham, M.; Bendszus, M.; Nieswandt, B.; Stoll, G. Targeting platelets in acute experimental stroke: Impact on glycoprotein Ib, VI, and IIb/IIIb blockade on infarct size, functional outcome, and intracranial bleeding. Circulation 2007, 115, 2323-2330. [CrossRef]

136. Linke, B.; Schreiber, Y.; Picard-Willems, B.; Slattery, P.; Nüsing, R.M.; Harder, S.; Geisslinger, G.; Scholich, K. Activated platelets induce an anti-inflammatory response of monocytes/macrophages through cross-regulation of PGE2 and cytokines. Mediators Inflamm. 2017, 2017, 1463216. [CrossRef]

137. Tamura, S.; Suzuki, H.; Hirowatari, Y.; Hatase, M.; Nagasawa, A.; Matsuno, K.; Kobayashi, S.; Moriyama, T. Release reaction of brain-derived neurotrophic factor (BDNF) through PAR1 activation and its two distinct pools in human platelets. Thromb. Res. 2011, 128, e55-e66. [CrossRef] [PubMed]

138. Schäbitz, W.R.; Steigleder, T.; Cooper-Kuhn, C.M.; Schwab, S.; Sommer, C.; Schneider, A.; Kuhn, H.G. Intravenous brainderived neurotrophic factor enhances poststroke sensorimotor recovery and stimulates neurogenesis. Stroke 2007, 38, 2165-2172. [CrossRef] [PubMed]

139. Ramos-Cejudo, J.; Gutiérrez-Fernández, M.; Otero-Ortega, L.; Rodríguez-Frutos, B.; Fuentes, B.; Vallejo-Cremades, M.T.; Navarro Hernanz, T.; Cerdán, S.; Díez-Tejedor, E. Brain-derived neurotrophic factor administration mediated oligodendrocyte differentiation and myelin formation in subcortical ischemic stroke. Stroke 2015, 46, 221-228. [CrossRef] [PubMed]

140. Ramiro, L.; Simats, A.; Berrocoso, T.G.; Montaner, J. Inflammatory molecules might become both biomarkers and therapeutic targets for stroke management. Ther. Adv. Neurol. Disord. 2018, 11, 1-24. [CrossRef]

141. Yang, C.; Hawkins, K.E.; Doré, S.; Candelario-Jalil, E. Neuroinflammatory mechanisms of blood-brain barrier damage in ischemic stroke. Am. J. Physiol. Cell Physiol. 2019, 316, C135-C153. [CrossRef] [PubMed]

142. Iadecola, C.; Anrather, J. The immunology of stroke: From mechanisms to translation. Nat. Med. 2011, 17, 796-808. [CrossRef]

143. Rayasam, A.; Hsu, M.; Kijak, J.A.; Kissel, L.; Hernandez, G.; Sandor, M.; Fabry, Z. Immune responses in stroke: How the immune system contributes to damage and healing after stroke and how this knowledge could be translated to better cures? Immunology 2018, 154, 363-376. [CrossRef] [PubMed]

144. Ozaki, E.; Campbell, M.; Doyle, S.L. Targeting the NLRP3 inflammasome in chronic inflammatory diseases: Current perspectives. J. Inflamm. Res. 2015, 8, 15-27.

145. Yang, Y.; Wang, H.; Kouadir, M.; Song, H.; Shi, F. Recent advances in the mechanisms of NLRP3 inflammasome activation and its inhibitors. Cell Death Dis. 2019, 10, 128-139. [CrossRef]

146. Tuttolomondo, A.; Puleo, M.G.; Velardo, M.C.; Corpora, F.; Daidone, M.; Pinto, A. Molecular biology of atherosclerotic ischemic strokes. Int. J. Mol. Sci. 2020, 21, 9372. [CrossRef]

147. Ormstad, H.; Aass, H.C.D.; Lund-Sørensen, N.; Amthor, K.-F.; Sandvik, L. Serum levels of cytokines and C-reactive protein in acute ischemic stroke patients, and their relationship to stroke lateralization, type, and infarct volume. J. Neurol. 2012, 258, 677-685. [CrossRef]

148. Rothwell, N.J. Interleukin-1 and neuronal injury: Mechanisms, modification, and therapeutic potential. Brain Behav. Immun. 2003, 17, 152-157. [CrossRef]

149. Emsley, H.C.A.; Smith, C.J.; Gavin, C.M.; Georgiou, R.F.; Vail, A.; Barberan, M.E.; Illingworth, K.; Scarth, S.; Wickramasinghe, V.; Hoadley, M.E.; et al. Clinical outcome following acute ischaemic stroke relates to both activation and autoregulatory inhibition of cytokine production. BMC Neurol. 2007, 7, 1-12. [CrossRef] [PubMed]

150. Yamasaki, Y.; Matsuura, N.; Shozuhara, H.; Onodera, H.; Itoyama, Y.; Kogure, K. Interleukin-1 as a pathogenetic mediator of ischemic brain damage in rats. Stroke 1995, 26, 676-680. [CrossRef]

151. Boutin, H.; LeFeuvre, R.A.; Horai, R.; Asano, M.; Iwakura, Y.; Rothwell, N.J. Role of IL-1alpha and IL-1beta in ischemic brain damage. J. Neurosci. 2001, 21, 5528-5534. [CrossRef]

152. Smith, C.J.; Emsley, H.C.; Udeh, C.; Vail, A.; Hoadley, M.E.; Rothwell, N.J.; Tyrrell, P.J.; Hopkins, S.J. Interleukin-1 receptor antagonist reverses stroke-associated peripheral immune suppression. Cytokine 2012, 58, 384-389. [CrossRef] [PubMed] 
153. Smith, C.J.; Hulme, S.; Vail, A.; Heal, C.; Parry-Jones, A.R.; Scarth, S.; Hopkins, K.; Hoadley, M.; Allan, S.M.; Rothwell, N.J.; et al. SCIL-STROKE (Subcutaneous interleukin-1 receptor antagonist in ischemic stroke): A randomized controlled phase 2 trial. Stroke 2018, 49, 1210-1216. [CrossRef]

154. Pasin, L.; Cavalli, G.; Navalesi, P.; Sella, N.; Landoni, G.; Yavorovskiy, A.G.; Likhvantsev, V.V.; Zangrillo, A.; Dagna, L.; Monti, G. Anakinra for patients with COVID-19: A meta-analysis of non-randomized cohort studies. Eur. J. Intern. Med. 2021, 86, 34-40. [CrossRef] [PubMed]

155. Kyriazopoulou, E.; Poulakou, G.; Milionis, H.; Metallidis, S.; Adamis, G.; Tsiakos, K.; Fragkou, A.; Rapti, A.; Damoulari, C.; Fantoni, M.; et al. Early treatment of COVID-19 with anakinra guided by soluble urokinase plasminogen receptor plasma levels: A double-blind, randomized controlled phase III trial. Nature Med. 2021, 27, 1752-1760. [CrossRef]

156. Liu, T.; Clark, R.K.; McDonnell, P.C.; Young, P.R.; White, R.F.; Barone, F.C.; Feuerstein, G.Z. Tumor necrosis factor-alpha expression in ischemic neurons. Stroke 1994, 25, 1481-1488. [CrossRef]

157. Stone, M.J.; Hayward, J.A.; Huang, C.; Huma, Z.E.; Sanchez, J. Mechanisms of regulation of the chemokine-receptor network. Int J. Mol. Sci. 2017, 18, 342. [CrossRef] [PubMed]

158. Bartsch, J.W.; Wildeboer, D.; Koller, G.; Naus, S.; Rittger, A.; Moss, M.L.; Minai, Y.; Jockusch, H. Tumor necrosis factor- $\alpha$ (TNF- $\alpha$ ) regulates shedding of TNF- $\alpha$ receptor 1 by the metalloprotease-disintegrin ADAM8: Evidence for a protease-regulated feedback loop in neuroprotection. J. Neurosci. 2010, 30, 12210-12218. [CrossRef]

159. Takata, F.; Dohgu, S.; Matsumoto, J.; Takahashi, H.; Machida, T.; Wakigawa, T.; Harada, E.; Miyaji, H.; Koga, M.; Nishioku, T.; et al. Brain pericytes among cells constituting the blood-brain barrier are highly sensitive to tumor necrosis factor- $\alpha$, releasing matrix metalloproteinase-9 and migrating in vitro. J. Neuroinflamm. 2011, 8, 106. [CrossRef]

160. Ginis, I.; Jaiswal, R.; Klimanis, D.; Liu, J.; Greenspon, J.; Hallenbeck, J.M. TNF-alpha-induced tolerance to ischemic injury involves differential control of NF-kappaB transactivation: The role of NF-kappaB association with p300 adaptor. J. Cereb. Blood Flow Metab. 2002, 22, 142-152. [CrossRef] [PubMed]

161. Erta, M.; Quintana, A.; Hidalgo, J. Interleukin-6, a major cytokine in the central nervous system. Int. J. Biol. Sci. 2012, 8, 1254-1266. [CrossRef] [PubMed]

162. Sotgiu, S.; Zanda, B.; Marchetti, B.; Fois, M.L.; Arru, G.; Pes, G.M.; Salaris, F.S.; Arru, A.; Pirisi, A.; Rosati, G. Inflammatory biomarkers in blood of patients with acute brain ischemia. Eur. J. Neurol. 2006, 13, 505-513. [CrossRef]

163. Bustamante, A.; Sobrino, T.; Giralt, D.; Garcia-Berrocoso, T.; Llombart, V.; Ugarizza, I.; Espadaler, M.; Rodriguez, N.; Sudlow, C.; Castellanos, M.; et al. Prognostic value of blood interleukin-6 in the prediction of functional outcome after stroke: A systematic review and meta-analysis. J. Neuroimmunol. 2014, 15, 215-224. [CrossRef]

164. Beridze, M.; Sanikidze, T.; Shakarishvilil, R.; Intskirveli, N.; Bornstein, N.M. Selected acute phase CSF factors in ischemic stroke: Findings and prognostic value. BMC Neurol. 2011, 11, 41-48. [CrossRef] [PubMed]

165. Connel, B.J.; Gordon, J.R.; Saleh, T.M. ELR-CXC chemokine antagonism is neuroprotective in a rat model of ischemic stroke. Neurosci. Lett. 2015, 606, 117-122. [CrossRef] [PubMed]

166. Villa, P.; Triulzi, S.; Cavalieri, B.; Di Bitondo, R.; Bertini, R.; Barbera, S.; Bigini, P.; Mennini, T.; Gelosa, P.; Tremoli, E.; et al. The interleukin-8 (IL-8/CXCL8) receptor inhibitor reparixin improves neurological deficits and reduces long-term inflammation in permanent and transient cerebral ischemia in rats. Mol. Med. 2007, 13, 125-133. [CrossRef]

167. Pelidou, S.H.; Kostulas, N.; Matusevicius, D.; Kivisäkk, P.; Kostulas, V.; Link, H. High levels of IL-10 secreting cells are present in blood in cerebrovascular diseases. Eur. J. Neurol. 1999, 6, 437-442. [CrossRef]

168. O'Garra, A.; Vieira, P.L.; Vieira, P.; Goldfeld, A.E. IL-10-producing and naturally occurring CD4+ Tregs: Limiting collateral damage. J. Clin. Investig. 2004, 114, 1372-1378. [CrossRef]

169. Vitkovic, L.; Maeda, S.; Sternberg, E. Anti-inflammatory cytokines: Expression and action in the brain. Neuroimmunomodulation 2001, 9, 295-312. [CrossRef] [PubMed]

170. Spera, P.A.; Ellison, J.A.; Feuerstein, G.Z.; Barone, F.C. IL-10 reduces rat brain injury following focal stroke. Neurosci. Lett. 1998, 251, 189-192. [CrossRef]

171. Ooboshi, H.; Ibayashi, S.; Shichita, T.; Kumai, Y.; Takada, J.; Ago, T.; Arakawa, S.; Sugimori, H.; Kamouchi, M.; Kitazono, T.; et al. Post-ischemic gene transfer of interleukin-10 protects against both focal and global brain ischemia. Circulation 2005, 111, 913-919. [CrossRef] [PubMed]

172. Vila, N.; Castillo, J.; Dávalos, A.; Chamorro, A. Proinflammatory cytokines and early neurological worsening in ischemic stroke. Stroke 2000, 31, 2325-2329. [CrossRef] [PubMed]

173. Yushchenko, M.; Mäder, M.; Elitok, E.; Bitsch, A.; Dressel, A.; Tumani, H.; Bogumil, T.; Kitze, B.; Poser, S.; Weber, F. Interferon-beta$1 \mathrm{~b}$ decreased matrix metalloproteinase-9 serum levels in primary progressive multiple sclerosis. J. Neurol. 2003, 250, 1224-1228. [CrossRef] [PubMed]

174. Müller, M.; Frese, A.; Nassenstein, I.; Hoppen, M.; Marziniak, M.; Ringelstein, E.B.; Kim, K.S.; Schäbitz, W.-R.; Kraus, J. Serum from interferon- $\beta-1 b$ treated patients with early multiple sclerosis stabilizes the blood-brain barrier in vitro. Mult. Scler. J. Exp. Transl. Clin. 2012, 18, 236-239. [CrossRef]

175. Defazio, G.; Livrea, P.; Giorelli, M.; Martino, D.; Roselli, F.; Ricchiuti, F.; Trojano, M. Interferon beta-1a downregulates TNFalphainduced intercellular adhesion molecule 1 expression on brain microvascular endothelial cells through a tyrosine kinase-dependent pathway. Brain Res. 2000, 881, 227-230. [CrossRef] 
176. Veldhuis, W.B.; Derksen, J.W.; Floris, S.; Van Der Meide, P.H.; De Vries, H.E.; Schepers, J.; Vos, I.M.P.; Dijkstra, C.D.; Kapelle, L.J.; Nicolay, K.; et al. Interferon-beta blocks infiltration of inflammatory cells and reduces infarct volume after ischemic stroke in the rat. J. Cereb. Blood Flow Metab. 2003, 23, 1029-1039. [CrossRef] [PubMed]

177. Bonaventura, A.; Liberale, L.; Vecchie, A.; Casula, M.; Carbone, F.; Dallegri, F.; Montecucco, F. Update on inflammatory biomarkers and treatments in ischemic stroke. Int. J. Mol. Sci. 2016, 17, 1967. [CrossRef]

178. Ma, M.; Ma, Y.; Yi, X.; Guo, R.; Zhu, W.; Fan, X.; Xu, G.; Frey, W.H., II; Liu, X. Intranasal delivery of transforming growth factor-beta 1 in mice after stroke reduces infarct volume and increases neurogenesis in the subventricular zone. BMC Neurosci. 2008, 9, 117. [CrossRef]

179. Rossi, D.; Zlotnik, A. The biology of chemokines and their receptors. Annu. Rev. Immunol. 2000, 18, 217-242. [CrossRef]

180. Cekanaviciute, E.; Buckwalter, M.S. Astrocytes: Integrative regulators of neuroinflammation in stroke and other neurological diseases. Neurotherapeuthics 2016, 13, 685-701. [CrossRef]

181. Rietdijk, C.D.; Van Wezel, R.J.A.; Garssen, J.; Kraneveld, A.D. Neuronal toll-like receptors and neuro-immunity in Parkinson's disease, Alzheimer's disease and stroke. Neuroimmunol. Neuroinflamm. 2016, 3, 27. [CrossRef]

182. Stamatovic, S.; Shakui, P.; Keep, R.F.; Moore, B.B.; Kunkel, S.L.; Van Rooijen, N.; Andjelkovic, A.V. Monocyte chemoattractant protein-1 regulation of blood-brain barrier permeability. J. Cereb. Blood Flow Metab. 2005, 25, 593-606. [CrossRef]

183. Rostène, W.; Dansereau, M.A.; Godefroy, D.; Van Steenwinckel, J.; Reaux-Le Goazigo, A.; Mélik-Parsadaniantz, S.; Apartis, E.; Hunot, S.; Beaudet, N.; Sarret, P. Neurochemokines: A menage a trois providing new insights on the functions of chemokines in the central nervous system. J. Neurochem. 2011, 118, 680-694. [CrossRef]

184. Weiss, J.M.; Downie, S.A.; Lyman, W.D.; Berman, J.W. Astrocyte-derived monocyte chemoattractant protein-1 directs the transmigration of leukocytes across a model of the human blood-brain barrier. J. Immunol. 1998, 161, 6896-6903.

185. Dimitrijevic, O.B.; Stamatovic, S.M.; Keep, R.F.; Andjelkovic, A.V. Effects of the chemokine CCL2 on blood-brain barrier permeability during ischemia-reperfusion injury. J. Cereb. Blood Flow Metab. 2006, 26, 797-810. [CrossRef]

186. Dénes, Á.; Ferenczi, S.; Halász, J.; Környei, Z.; Kovács, K.J. Role of CX3CR1 (fractalkine receptor) in brain damage and inflammation induced by focal cerebral ischemia in mouse. J. Cereb. Blood Flow Metab. 2008, 28, 1707-1721. [CrossRef] [PubMed]

187. Cipriani, R.; Villa, P.; Chece, G.; Lauro, C.; Paladini, A.; Micotti, E.; Perego, C.; De Simoni, M.-G.; Fredholm, B.B.; Eusebi, F.; et al. CX3CL1 is neuroprotective in permanent focal cerebral ischemia in rodents. J. Neurosci. 2011, 31, 16327-16335. [CrossRef] [PubMed]

188. Wang, Y.; Huang, J.; Li, Y.; Yang, G.Y. Roles of chemokine CXCL 12 and its receptors in ischemic stroke. Curr. Drug Targets. 2012, 13, 166-172. [CrossRef]

189. Terao, S.; Yilmaz, G.; Stokes, K.Y.; Russel, J.; Ishikawa, M.; Kawase, T.; Granger, D.N. Blood cell-derived RANTES mediates cerebral microvascular dysfunction, inflammation, and tissue injury after focal ischemia-reperfusion. Stroke 2008, 39, 2560-2570. [CrossRef]

190. Ruscher, K.; Kuric, E.; Liu, Y.; Walter, H.L.; Issazadeh-Navikas, S.; Englund, E.; Wieloch, T. Inhibition of CXCL 12 signaling attenuates the postischemic immune response and improves functional recovery after stroke. J. Cereb. Blood Flow Metab. 2013, 33, 1225-1234. [CrossRef] [PubMed]

191. Hill, W.D.; Hess, D.C.; Martin-Studdard, A.; Carothers, J.J.; Zheng, J.; Hale, D.; Maeda, M.; Fagan, S.C.; Carroll, J.E.; Conway, S.J. SDF-1 (CXCL12) is upregulated in the ischemic penumbra following stroke: Association with bone marrow cell homing to injury. J. Neuropathol. Experiment. Neurol. 2004, 63, 84-96. [CrossRef] [PubMed]

192. Shyu, W.C.; Lin, S.Z.; Yen, P.S.; Su, C.Y.; Chen, D.C.; Wang, H.J.; Li, H. Stromal cell-derived factor-1 alpha promotes neuroprotection, angiogenesis, and mobilization/homing of bone marrow-derived cells in stroke rats. J. Pharmacol. Exp. Ther. 2008, 324, 834-849. [CrossRef]

193. Yang, Y.; Rosenberg, G.A. Matrix metalloproteinases as therapeutic targets for stroke. Brain Res. 2015, 1623, 30-38. [CrossRef]

194. Morancho, A.; Rosell, A.; Garcia-Bonilla, L.; Montaner, J. Metalloproteinase and stroke infarct size: Role for anti-inflammatory treatment? Ann. N. Y. Acad. Sci. 2010, 207, 123-133. [CrossRef]

195. Candelario-Jalil, E. Injury and repair mechanisms in ischemic stroke: Considerations for the development of novel neurotherapeutics. Curr. Opin. Investig. Drugs 2009, 10, 644-654. [PubMed]

196. Rosenberg, G.A.; Yang, Y. Vasogenic edema due to tight junction disruption by matrix metalloproteinases in cerebral ischemia. Neurosurg. Focus. 2007, 22, E4. [CrossRef]

197. Candelario-Jalil, E.; Yang, Y.; Rosenberg, G.A. Diverse roles of matrix metalloproteinases and tissue inhibitors of metalloproteinases in neuroinflammation and cerebral ischemia. Neuroscience 2009, 158, 983-994. [CrossRef] [PubMed]

198. Cunningham, L.A.; Wetzel, M.; Rosenberg, G.A. Multiple roles for MMPs and TIMPs in cerebral ischemia. Glia 2005, 50, 329-339. [CrossRef]

199. Ma, F.; Rodriguez, S.; Buxo, X.; Morancho, A.; Riba-Llena, I.; Carrera, A.; Bustamante, A.; Giralt, D.; Montaner, J.; Martinez, C.; et al. Plasma matrix metalloproteinases in patients during intensive rehabilitation therapy. Arch. Phys. Med. Rehabil. 2016, 97, 1832-1840. [CrossRef]

200. Zhao, B.-Q.; Wang, S.; Kim, H.-Y.; Storrie, H.; Rosen, B.R.; Mooney, D.J.; Wang, X.; Lo, E.H. Role of matrix metalloproteinases in delayed cortical responses after stroke. Nature Med. 2006, 12, 441-445. [CrossRef] [PubMed]

201. Bergers, G.; Brekken, R.; McMahon, G.; Vu, T.H.; Itoh, T.; Tamaki, K.; Tanzawa, K.; Thorpe, P.; Itohara, S.; Werb, Z.; et al. Matrix metalloproteinase-9 triggers the angiogenic switch during carcinogenesis. Nat. Cell. Biol. 2000, 2, 737-744. [CrossRef] 
202. Shi, L.; Rocha, M.; Leak, R.K.; Zhao, J.; Bhatia, T.N.; Mu, H.; Wei, Z.; Yu, F.; Weiner, S.L.; Ma, F.; et al. A new era for stroke therapy: Integrating neurovascular protection with optimal reperfusion. J. Cereb. Blood Flow Metab. 2018, 38, 2073-2091. [CrossRef] [PubMed]

203. Shichita, T.; Ito, M.; Yoshimura, A. Post-ischemic inflammation regulates neural damage and protection. Front. Cell. Neurosci. 2014, 8, 319. [CrossRef]

204. Rajkovic, O.; Potjewyd, G.; Pinteaux, E. Regenerative medicine therapies for targeting neuroinflammation after stroke. Front. Neurol. 2018, 9, 734. [CrossRef]

205. Jin, K.; Wang, X.; Xie, L.; Mao, X.O.; Zhu, W.; Wang, Y.; Shen, J.; Mao, Y.; Banwait, S.; Greenberg, D.A. Evidence for stroke-induced neurogenesis in the human brain. Proc. Natl. Acad. Sci. USA 2006, 103, 13198-13202. [CrossRef] [PubMed]

206. Rahman, A.A.; Amruta, N.; Pinteaux, E.; Bix, G.J. Neurogenesis after stroke: A therapeutic perspective. Transl. Stroke Res. 2021, 12,1-14. [CrossRef]

207. Zhang, R.L.; Zhang, Z.G.; Zhang, L.; Chopp, M. Proliferation and differentiation of progenitor cells in the cortex and subventricular zone in the adult rat after focal cerebral ischemia. Neuroscience 2001, 105, 33-41. [CrossRef]

208. Arvidsson, A.; Collin, T.; Kirik, D.; Kokaia, Z.; Lindvall, O. Neuronal replacement from endogenous precursors in the adult brain after stroke. Nat. Med. 2002, 8, 963-970. [CrossRef] [PubMed]

209. Yan, Y.P.; Sailor, K.A.; Vemuganti, R.; Dempsey, R.J. Insulin-like growth factor-1 is an endogenous mediator of focal ischemiainduced neural progenitor proliferation. Eur. J. Neurosci. 2006, 24, 45-54. [CrossRef] [PubMed]

210. Chen, J.; Zacharek, A.; Zhang, C.; Jiang, H.; Li, Y.; Roberts, C.; Lu, M.; Kapke, A.; Chopp, M. Endothelial nitric oxide synthase regulates brain-derived neurotrophic factor expression and neurogenesis after stroke in mice. J. Neurosci. 2005, 25, $2366-2375$. [CrossRef]

211. Jin, K.; Zhu, Y.; Sun, Y.; Mao, X.O.; Xie, L.; Greenberg, D.A. Vascular endothelial growth factor (VEGF) stimulates neurogenesis in vitro and in vivo. Proc. Natl. Acad. Sci. USA 2002, 99, 11946-11950. [CrossRef]

212. Yan, Y.P.; Sailor, K.A.; Lang, B.T.; Park, S.W.; Vemuganti, R.; Dempsey, R.J. Monocyte chemoattractant protein-1 plays a critical role in neuroblast migration after focal cerebral ischemia. J. Cereb. Blood Flow Metab. 2007, 27, 1213-1224. [CrossRef]

213. Wang, L.; Zhang, Z.G.; Zhang, R.L.; Gregg, S.R.; Hozeska-Solgot, A.; LeTourneau, Y.; Wang, Y.; Chopp, M. Matrix metalloproteinase 2 (MMP2) and MMP9 secreted by erythropoietin-activated endothelial cells promote neural progenitor cell migration. J. Neurosci. 2006, 26, 5996-6003. [CrossRef] [PubMed]

214. Madelaine, R.; Sloan, S.A.; Huber, N.; Notwell, J.H.; Leung, L.C.; Skariah, G.; Halluin, C.; Pasca, S.P.; Bejerano, G.; Krasnow, M.A.; et al. MicroRNA-9 couples brain neurogenesis and angiogenesis. Cell Rep. 2017, 20, 1533-1542. [CrossRef]

215. Zhang, S.-J.; Wang, R.-L.; Zhao, H.-P.; Tao, Z.; Li, J.-C.; Ju, F.; Han, Z.-P.; Ma, Q.-F.; Liu, P.; Ma, S.-B.; et al. MEPO promotes neurogenesis and angiogenesis but suppresses gliogenesis in mice with acute ischemic stroke. Eur. J. Pharamacol. 2019, 849, 1-10. [CrossRef]

216. Hayashi, T.; Noshita, N.; Sugawara, T.; Chan, P.H. temporal profile of angiogenesis and expression of related genes in the brain after ischemia. J. Cereb. Blood Flow Metab. 2003, 23, 166-180. [CrossRef]

217. Islam, O.; Gong, X.; Rose-John, S.; Heese, K. Interleukin-6 and neural stem cells: More than gliogenesis. Mol. Biol. Cell 2009, 20, 188-199. [CrossRef]

218. Vallières, L.; Campbell, I.L.; Gage, F.H.; Sawchenko, P.E. Reduced hippocampal neurogenesis in adult transgenic mice with chronic astrocytic production of interleukin-6. J. Neurosci. 2002, 22, 486-492. [CrossRef]

219. Zhang, Y.; Xu, D.; Qi, H.; Yuan, Y.; Liu, H.; Yao, S.; Yuan, S.; Zhang, J. Enriched environment promotes post-stroke neurogenesis through NF-kB-mediated secretion of IL-17A from astrocytes. Brain Res. 2018, 1687, 20-31. [CrossRef]

220. Aarum, J.; Sandberg, K.; Haeberlein, S.L.; Persson, M.A. Migration and differentiation of neural precursor cells can be directed by microglia. Proc. Natl. Acad. Sci. USA 2003, 100, 15983-15988. [CrossRef]

221. Guan, J.; Williams, C.; Gunning, M.; Mallard, C.; Gluckman, P. The effects of IGF-1 treatment after hypoxic-ischemic brain injury in adult rats. J. Cereb. Blood Flow Metab. 1993, 13, 609-616. [CrossRef]

222. Pardridge, W.M. Drug delivery to the brain. J. Cereb. Blood Flow Metab. 1997, 17, 713-731. [CrossRef]

223. Guan, J. Insulin-like growth factor -1 (IGF-1) derived neuropeptides, a novel strategy for the development of pharmaceuticals for managing ischemic brain injury. CNS Neurosci. Ther. 2011, 17, 250-255. [CrossRef]

224. Guan, J.; Thomas, G.B.; Lin, H.; Mathai, S.; Bachelor, D.C.; Gluckman, P.D. Neuroprotective effects of the N-terminal tripeptide of insulin-like growth factor-1, glycine-proline-glutamate (GPE) following intravenous infusion in hypoxic-ischemic adult rats. Neuropharmacology 2004, 47, 892-903. [CrossRef] [PubMed]

225. Saura, J.; Curatolo, L.; Williams, C.E.; Gatti, S.; Benatti, L.; Peeters, C.; Guan, J.; Dragunow, M.; Post, C.; Faull, R.L.; et al. Neuroprotective effects of Gly-Pro-Glu, the N-terminal tripeptide of IGF-1, in the hippocampus in vitro. Neuroreport 1999, 10, 161-164. [CrossRef]

226. Kaplan, D.R.; Miller, F.D. Neurotrophin signal transduction in the nervous system. Curr. Opin. Neurobiol. 2000, 10, 381-391. [CrossRef]

227. Gaidin, S.G.; Turovskaya, M.V.; Gavrish, M.S.; Babaev, A.A.; Maltseva, V.N.; Blinova, E.V.; Turovsky, E.A. The selective BDNF overexpression in neurons protects neuroglial networks against OGD and glutamate-induced excitotoxicity. Int. J. Neurosci. 2020, 130, 363-383. [CrossRef] 
228. Liu, W.; Wang, X.; O'Connor, M.; Wang, G.; Han, F. Brain-Derived Neurotrophic Factor and its potential therapeutic role in stroke comorbidities. Neural Plast. 2020, 2020, 1969482. [CrossRef]

229. Mattson, M.P. Glutamate and neurotrophic factors in neuronal plasticity and disease. Ann. N. Y. Acad. Sci. 2008, 1144, 97-112. [CrossRef]

230. Li, Y.; Jia, Y.-C.; Cui, K.; Li, N.; Zheng, Z.-Y.; Wang, Y.-Z.; Yuan, X.-B. Essential role of TRPC channels in the guidance of nerve growth cones by brain-derived neurotrophic factor. Nature 2005, 434, 894-898. [CrossRef] [PubMed]

231. Labelle, C.; Leclerc, N. Exogenous BDNF, NT-3 and NT-4 differentially regulate neurite outgrowth in cultured hippocampal neurons. Brain Res. Dev. Brain Res. 2000, 123, 1-11. [CrossRef]

232. Tanaka, Y.; Tanaka, R.; Liu, M.; Hattori, N.; Urabe, T. Cilostazol attenuates ischemic brain injury and enhances neurogenesis in the subventricular zone of adult mice after transient focal cerebral ischemia. Neuroscience 2010, 17, 1367-1376. [CrossRef]

233. Chen, S.J.; Tsai, J.C.; Lin, C.Y.; Chang, C.K.; Tseng, T.H.; Chien, C.L. Brain-derived neurotrophic factor-transfected and nontransfected 3T3 fibroblasts enhance migratory neuroblasts and functional restoration in mice with intracerebral hemorrhage. J. Neuropathol. Exp. Neurol. 2012, 71, 1123-1136. [CrossRef]

234. Kurozumi, K.; Nakamura, K.; Tamiya, T.; Kawano, Y.; Kobune, M.; Hirai, S.; Uchida, H.; Sasaki, K.; Ito, Y.; Kato, K.; et al. BDNF gene-modified mesenchymal stem cells promote functional recovery and reduce infarct size in the rat middle cerebral artery occlusion model. Mol. Ther. 2004, 9, 189-197. [CrossRef]

235. Alcantara, C.C.; Garcia-Salazar, L.F.; Silva-Couto, M.A.; Santos, G.L.; Reisman, D.S.; Russo, T.L. Post-stroke BDNF concentration changes following physical exercise: A systematic review. Front. Neurol. 2018, 9, 637. [CrossRef]

236. Liao, G.Y.; Kinney, C.E.; An, J.J.; Xu, B. TrkB-expressing neurons in the dorsomedial hypothalamus are necessary and sufficient to suppress homeostatic feeding. Proc. Natl. Acad. Sci. USA 2019, 116, 3256-3261. [CrossRef] [PubMed]

237. Zhang, Y.; Pardridge, W.M. Neuroprotection in transient focal brain ischemia after delayed intravenous administration of brainderived neurotrophic factor conjugated to a blood-brain barrier drug targeting system. Stroke 2001, 32, 1378-1384. [CrossRef] [PubMed]

238. Harris, N.M.; Ritzel, R.; Mancini, N.S.; Jian, Y.; Yi, X.; Manickam, D.S.; Banks, W.A.; Kabanov, A.V.; McCullough, L.D.; Verma, R. Nano-particle delivery of brain derived neurotrophic factor after focal cerebral ischemia reduces tissue injury and enhances behavioral recovery. Pharmacol. Biochem. Behav. 2016, 150-151, 48-56. [CrossRef] [PubMed]

239. Fu, A.; Wang, Y.; Zhan, L.; Zhou, R. Targeted delivery of proteins into the central nervous system mediated by rabies virus glycoprotein-derived peptide. Pharm. Res. 2012, 29, 1562-1569. [CrossRef]

240. Gottlieb, M.; Matute, C. Expression of nerve growth factor in astrocytes of the hippocampal CA1 area following transient forebrain ischemia. Neuroscience 1999, 91, 1027-1034. [CrossRef]

241. Kordower, J.H.; Winn, S.R.; Liu, Y.-T.; Mufson, E.J.; Sladek, J.R.; Hammang, J.P.; Baetge, E.E.; Emerich, D.F. The aged monkey basal forebrain: Rescue and sprouting of axotomized basal forebrain neurons after grafts of encapsulated cells secreting human nerve growth factor. Proc. Natl. Acad. Sci. USA 1994, 91, 10898-10902. [CrossRef]

242. Petty, B.G.; Cornblath, D.R.; Adornato, B.T.; Chaudhry, V.; Flexner, C.; Wachsman, M.; Sinicropi, D.; Burton, L.E.; Peroutka, S.J. The effect of systemically administered recombinant human nerve growth factor in healthy human subjects. Ann. Neurol. 1994, 36, 244-246. [CrossRef] [PubMed]

243. Airaksinen, M.S.; Saarma, M. The GDNF family: Signalling, biological functions and therapeutic value. Nat. Rev. Neurosci. 2002, 3, 383-394. [CrossRef] [PubMed]

244. Arvidsson, A.; Kokaia, Z.; Airaksinen, M.S.; Saarma, M.; Lindvall, O. Stroke induces widespread changes of gene expression for glial cell line-derived neurotrophic factor family receptors in the adult rat brain. Neuroscience 2001, 106, 27-41. [CrossRef]

245. Wang, Y.; Lin, S.Z.; Chiou, A.L.; Williams, L.R.; Hoffer, B.J. Glial cell line-derived neurotrophic factor protects against ischemiainduced injury in the cerebral cortex. J. Neurosci. 1997, 17, 4341-4348. [CrossRef] [PubMed]

246. Arvidsson, A.; Kirik, D.; Lundberg, C.; Mandel, R.J.; Andsberg, G.; Kokaia, Z.; Lindvall, O. Elevated GDNF levels following viral vector-mediated gene transfer can increase neuronal death after stroke in rats. Neurobiol Dis. 2003, 14, 542-556. [CrossRef]

247. Kobayashi, T.; Ahlenius, H.; Thored, P.; Kobayashi, R.; Kokaia, Z.; Linvall, O. Intracerebral infusion of glial cell line-derived neurotrophic factor promotes striatal neurogenesis after stroke in adult rats. Stroke 2006, 37, 2361-2367. [CrossRef]

248. Lang, A.E.; Gill, S.; Patel, N.K.; Lozano, A.; Nutt, J.G.; Penn, R.; Brooks, D.J.; Hotton, G.; Moro, E.; Heywood, P.; et al. Randomized controlled trial of intraputamenal glial cell line-derived neurotrophic factor infusion in Parkinson disease. Ann. Neurol. 2006, 59, 459-466. [CrossRef]

249. Purvis, G.S.D.; Solito, E.; Thiemermann, C. Annexin-A1: Therapeutic potential in microvascular disease. Front. Immunol. 2019, 10, 938. [CrossRef]

250. Luo, Z.Z.; Gao, Y.; Sun, N.; Zhao, Y.; Wang, J.; Tian, B.; Shi, J. Enhancing the interaction between annexin-1 and formil peptide receptors regulates microglial activation to protect neurons from ischemia-like injury. J. Neuroimmunol. 2014, 276, 24-36. [CrossRef] [PubMed]

251. Xu, X.; Gao, W.; Li, L.; Hao, J.; Yang, B.; Wang, T.; Li, L.; Bai, X.; Li, F.; Ren, H.; et al. Annexin A1 protects against cerebral ischemia-reperfusion injury by modulating microglia/macrophage polarization via FPR2/ALX-dependent AMPK-mTOR pathway. J. Neuroinflamm. 2021, 18, 119. [CrossRef]

252. Zhang, W.-F.; Jin, Y.-C.; Li, X.-M.; Yang, Z.; Wang, D.; Cui, J.-J. Protective effects of leptin against cerebral ischemia/reperfusion injury (review). Exp. Ther. Med. 2019, 17, 3282-3290. [CrossRef] 
253. Geng, H.X.; Li, R.P.; Li, Y.G.; Wang, X.Q.; Zhang, L.; Deng, J.B.; Wang, L.; Deng, J.X. 14,15-EET suppresses neuronal apoptosis in ischemia-reperfusion through the mitochondrial pathway. Neurochem. Res. 2017, 42, 2841-2849. [CrossRef]

254. Amantea, D.; Tassorelli, C.; Russo, R.; Petrelli, F.; Morrone, L.A.; Bagetta, G.; Corasaniti, M.T. Neuroprotection by leptin in a rat model of permanent cerebral ischemia: Effects on STAT3 phosphorylation in discrete cells of the brain. Cell Death Dis. 2011, 2, e238. [CrossRef]

255. Deng, Z.H., Jr.; Yan, G.T.; Wang, L.H.; Zhang, J.Y.; Xue, H.; Zhang, K. Leptin relieves intestinal ischemia/reperfusion injury by promoting ERK1/2 phosphorylation and the NO signaling pathway. J. Trauma Acute Care Surg. 2012, 72, 143-149. [CrossRef] [PubMed]

256. Kwon, O.; Kim, K.W.; Kim, M.S. Leptin signalling pathways in hypothalamic neurons. Cell. Mol. Life Sci. 2016, $73,1457-1477$. [CrossRef]

257. Zhang, J.; Deng, Z.; Liao, J.; Song, C.; Liang, C.; Xue, H.; Wang, L.; Zhang, K.; Yan, G. Leptin attenuates cerebral ischemia injury through the promotion of energy metabolism via the PI3K/Akt pathway. J. Cereb. Blood Flow Metab. 2013, 33, 567-574. [CrossRef] [PubMed]

258. Verma, R.; Cronin, C.G.; Hudobenko, J.; Venna, V.R.; McCullough, L.D.; Liang, B.T. Deletion of the P2X4 receptor is neuroprotective acutely, but induces a depressive phenotype during recovery from ischemic stroke. Brain Behav. Immun. 2017, 66, 302-312. [CrossRef] [PubMed]

259. Plane, J.M.; Shen, Y.; Pleasure, D.E.; Deng, W. Prospects for minocycline neuroprotection. Arch. Neurol. 2010, $67,1442-1448$. [CrossRef] [PubMed]

260. Morimoto, N.; Shimazawa, M.; Yamashima, T.; Nagai, H.; Hara, H. Minocycline inhibits oxidative stress and decreases in vitro and in vivo ischemic neuronal damage. Brain Res. 2005, 1044, 8-15. [CrossRef]

261. Matsukawa, N.; Yasuhara, T.; Hara, K.; Xu, L.; Maki, M.; Yu, G.; Kaneko, Y.; Ojika, K.; Hess, D.C.; Borlongan, C.V. Therapeutic targets and limits of minocycline neuroprotection in experimental ischemic stroke. BMC Neurosci. 2009, 10, 126. [CrossRef]

262. Machado, L.S.; Sazonova, I.; Kozak, A.; Wiley, D.C.; El-Remessy, A.B.; Ergul, A.; Hess, D.C.; Waller, J.L.; Fagan, S.C. Minocycline and tissue plasminogen activator for stroke: Assessment of interaction potential. Stroke 2009, 40, 3028-3033. [CrossRef]

263. Lampl, Y.; Boaz, M.; Gilad, R.; Loberboym, M.; Dabby, A.; Rapoport, A.; Anca-Hershkowitz, M.; Sadeh, M. Minocycline treatment in acute stroke: An open-label, evaluator-blinded study. Neurology 2007, 69, 1404-1410. [CrossRef] [PubMed]

264. Padma Srivastava, M.V.; Bhasin, A.; Bhatia, R.; Garg, A.; Gaikwad, S.; Prasad, K.; Singh, M.B.; Tripathi, M. Efficacy of minocycline in acute ischemic stroke: A single-blinded, placebo-controlled trial. Neurol. India 2012, 60, 23-28. [CrossRef]

265. Kohler, E.; Prentice, D.A.; Bates, T.R.; Hankey, G.J.; Claxton, A.; Van Heerden, J.; Blacker, D. Intravenous minocycline in acute stroke: A randomized, controlled pilot study and meta-analysis. Stroke 2013, 44, 2493-2499. [CrossRef] [PubMed]

266. Ashayeri Ahmadabad, R.; Mirzaasgari, Z.; Gorji, A.; Khaleghi Ghadiri, M. Toll-like receptor signaling pathways: Novel therapeutic targets for cerebrovascular disorders. Int. J. Mol. Sci. 2021, 22, 6153. [CrossRef]

267. Abdul, Y.; Abdelsaid, M.; Li, W.; Webb, R.C.; Sullivan, J.C.; Dong, G.; Ergul, A. Inhibition of Toll-like receptor-4 (TLR-4) improves neurobehavioral outcomes after acute ischemic stroke in diabetic rats: Possible role of vascular endothelial TLR-4. Mol. Neurobiol. 2019, 56, 1607-1617. [CrossRef] [PubMed]

268. Homepage on the Internet. Available online: www.clinicaltrials.gov (accessed on 12 November 2021).

269. Jackson, L.; Dong, G.; Althomali, W.; Sayed, M.A.; Eldahshan, W.; Baban, B.; Johnson, M.H.; Filosa, J.; Fagan, S.C.; Ergul, A. Delayed administration of angiotensin II type 2 receptor (AT2R) agonist compound 21 prevents the development of post-stroke cognitive impairment in diabetes through the modulation of microglia polarization. Transl. Stroke Res. 2019, 11, 762-775. [CrossRef]

270. Jackson-Cowan, L.; Eldahshan, W.; Dumanli, S.; Dong, G.; Jamil, S.; Abdul, Y.; Althomali, W.; Baban, B.; Fagan, S.C.; Ergul, A. Delayed administration of angiotensin receptor (AT2R) agonist C21 improves survival and preserves sensorimotor outcomes in female diabetic rats post-stroke through modulation of microglial activation. Int. J. Mol. Sci. 2021, 22, 1356. [CrossRef] [PubMed]

271. Liu, X.; Liu, J.; Zhao, S.; Zhang, H.; Cai, W.; Cai, M.; Ji, X.; Leak, R.K.; Gao, Y.; Chen, J.; et al. Interleukin-4 is essential for microglial/macrophage M2 polarization and long-term recovery after cerebral ischemia. Stroke 2016, 47, 498-504. [CrossRef]

272. Yang, Y.; Liu, H.; Zhang, H.; Ye, Q.; Wang, J.; Yang, B.; Mao, L.; Zhu, W.; Leak, R.K.; Xiao, B.; et al. ST2/IL-33-dependent microglial response limits acute ischemic brain injury. J. Neurosci. 2017, 37, 4692-4704. [CrossRef]

273. Clark, W.M.; Madden, K.P.; Rothlein, R.; Zivin, J.A. Reduction of central nervous system ischemic injury by monoclonal antibody to intercellular adhesion molecule. J. Neurosurg. 1991, 75, 623-627. [CrossRef] [PubMed]

274. Bowes, M.P.; Rothlein, R.; Fagan, S.C.; Zivin, J.A. Monoclonal antibodies preventing leukocyte activation reduce experimental neurologic injury and enhance efficacy of thrombolytic therapy. Neurology 1995, 45, 815-819. [CrossRef]

275. Cheng, Y.D.; Al-Khoury, L.; Zivin, J.A. Neuroprotection for ischemic stroke: Two decades of success and failure. NeuroRx 2004, 1, 36-45. [CrossRef] [PubMed]

276. Enlimomab Acute Stroke Trial Investigators. Use of anti-ICAM-1 therapy in ischemic stroke: Results of the Enlimomab Acute Stroke Trial. Neurology 2001, 57, 1428-1434. [CrossRef] [PubMed]

277. Bednar, M.M.; Gross, C.E.; Russell, S.R.; Fuller, S.P.; Ellenberger, C.L.; Schindler, E.; Klingbeil, C.; Vexler, V. Humanized antiL-selectin monoclonal antibody DREG200 therapy in acute thromboembolic stroke. Neurol. Res. 1998, 20, 403-408. [CrossRef] [PubMed] 
278. Prestigiacomo, C.J.; Kim, S.C.; Connolly, E.S.; Liao, H.; Yan, S.F.; Pinsky, D.J. CD 18-mediated neutrophil recruitment contributes to the pathogenesis of reperfused but not nonreperfused stroke. Stroke 1999, 30, 1110-1117. [CrossRef]

279. Garcia, J.H.; Liu, K.F.; Bree, M.P. Effects of CD11b/18 monoclonal antibody on rats with permanent middle cerebral artery occlusion. Am. J. Pathol. 1996, 148, 241-248.

280. Krams, M.; Lees, K.R.; Hacke, W.; Grieve, A.P.; Orgogozo, J.-M.; Ford, G.A.; ASTIN Study Investigators. Acute Stroke Therapy by Inhibition of Neutrophils (ASTIN): An adaptive dose-response study of UK-279,276 in acute ischemic stroke. Stroke 2003, 34, 2543-2548. [CrossRef]

281. Langhauser, F.; Kraft, P.; Göb, E.; Leinweber, J.; Schuhmann, M.K.; Lorenz, K.; Gelderblom, M.; Bittner, S.; Meuth, S.G.; Wiendl, H.; et al. Blocking of $\alpha 4$ integrin does not protect from acute ischemic stroke in mice. Stroke 2014, 45, 1799-1806. [CrossRef]

282. Becker, K.; Kindrick, D.; Relton, J.; Harlan, J.; Winn, R. Antibody to the alpha4 integrin decreases infarct size in transient focal cerebral ischemia in rats. Stroke 2001, 32, 206-211. [CrossRef]

283. Relton, J.K.; Sloan, K.E.; Frew, E.M.; Whalley, E.T.; Adams, S.P.; Lobb, R.R. Inhibition of alpha4 integrin protects against transient focal cerebral ischemia in normotensive and hypertensive rats. Stroke 2001, 32, 199-205. [CrossRef] [PubMed]

284. Llovera, G.; Hofmann, K.; Roth, S.; Salas-Pérdomo, A.; Ferrer-Ferrer, M.; Perego, C.; Zanier, E.R.; Mamrak, U.; Rex, A.; Party, H.; et al. Results of a preclinical randomized controlled multicenter trial (pRCT): Anti-CD49d treatment for acute brain ischemia. Sci. Transl. Med. 2015, 7, 299ra121. [CrossRef]

285. Elkins, J.; Veltkamp, R.; Montaner, J.; Johnston, S.C.; Singhal, A.B.; Becker, K.; Lansberg, M.G.; Tang, W.; Chang, I.; Muralidharan, K.; et al. Safety and efficacy of natalizumab in patients with acute ischaemic stroke (ACTION): A randomised, placebo-controlled, double-blind phase 2 trial. Lancet Neurol. 2017, 16, 217-226. [CrossRef]

286. Elkind, M.S.V.; Veltkamp, R.; Montaner, J.; Johnston, S.C.; Singhal, A.B.; Becker, K.; Lansberg, M.G.; Tang, W.; Kasliwal, R.; Elkins, J. Natalizumab in acute ischemic stroke (ACTION II): A randomized, placebo-controlled trial. Neurology 2020, 95, e1091-e1104. [CrossRef]

287. Liesz, A.; Zhou, W.; Mracskó, E.; Karcher, S.; Bauer, H.; Schwarting, S.; Sun, L.; Bruder, D.; Stegeman, S.; Cerwenka, A.; et al. Inhibition of lymphocyte trafficking shields the brain against deleterious neuroinflammation after stroke. Brain J. Neurol. 2011, 134, 704-720. [CrossRef]

288. Kieseier, B.C. The mechanism of action of interferon- $\beta$ in relapsing multiple sclerosis. CNS Drugs 2011, 25, 491-502. [CrossRef]

289. Liesz, A.; Suri-Payer, E.; Veltkamp, C.; Doerr, H.; Sommer, C.; Rivest, S.; Giese, T.; Veltkamp, R. Regulatory T cells are key cerebroprotective immunomodulators in acute experimental stroke. Nat. Med. 2009, 15, 192-199. [CrossRef]

290. Liesz, A.; Zhou, W.; Na, S.-Y.; Hämmerling, G.J.; Garbi, N.; Karcher, S.; Mracsko, E.; Backs, J.; Rivest, S.; Veltkamp, R. Boosting regulatory T cells limits neuroinflammation in permanent cortical stroke. J. Neurosci. 2013, 33, 17350-17362. [CrossRef] [PubMed]

291. Xie, L.; Sun, F.; Wang, J.; Mao, X.; Xie, L.; Yang, S.-H.; Su, D.-M.; Simpkins, J.W.; Greenberg, D.A.; Jin, K. mTOR signaling inhibition modulates macrophage/microglia-mediated neuroinflammation and secondary injury via regulatory $\mathrm{T}$ cells after focal ischemia. J. Immunol. 2014, 192, 6009-6019. [CrossRef] [PubMed]

292. Stubbe, T.; Ebner, F.; Richter, D.; Engel, O.; Klehmet, J.; Royl, G.; Meisel, A.; Nitsch, R.; Meisel, C.; Brandt, C. Regulatory T cells accumulate and proliferate in the ischemic hemispheres for up to 30 days after MCAO. J. Cereb. Blood Flow Metab. 2013, 33, 37-47. [CrossRef]

293. Na, S.-Y.; Mracsko, E.; Liesz, A.; Hünig, T.; Veltkamp, R. Amplification of regulatory T cells using a CD28 superagonist reduces brain damage after ischemic stroke in mice. Stroke 2015, 46, 212-220. [CrossRef] [PubMed]

294. Schuhmann, M.K.; Kraft, P.; Stoll, G.; Lorenz, K.; Meuth, S.G.; Windl, H.; Niewandt, B.; Sparwasser, T.; Beyersdorf, N.; Kerkau, T.; et al. CD28 superagonist-mediated boost of regulatory $\mathrm{T}$ cells increases thrombo-inflammation and ischemic neurodegeneration during the acute phase of experimental stroke. J. Cereb. Blood Flow Metab. 2015, 35, 6-10. [CrossRef]

295. Zhu, Z.; Fu, Y.; Tian, D.; Sun, N.; Han, W.; Chang, G.; Dong, Y.; Xu, X.; Liu, Q.; Huang, D.; et al. Combination of the immune modulator Fingolimod with alteplase in acute ischemic stroke: A pilot trial. Circulation 2015, 132, 1104-1112. [CrossRef]

296. Kobayashi, S.; Fukuma, S.; Ikenoue, T.; Fukuhara, S.; Kobayashi, S.; on behalf of the Japan Stroke databank. Effect of edaravone on neurological symptoms in real-world patients with acute ischemic stroke. Japan Stroke Databank. Stroke 2019, 50, 1805-1811. [CrossRef]

297. Cho, H.; Shukla, S. Role of edaravone as a treatment option for patients with amyotrophic lateral sclerosis. Pharmaceuticals 2020, 14, 29. [CrossRef] [PubMed]

298. Licata, G.; Tuttolomondo, A.; Corrao, S.; Di Raimondi, D.; Fernandez, P.; Caruso, C.; Avellone, G.; Pinto, A. Immunoinflammatory activation during the acute phase of lacunar and non-lacunar ischemic stroke: Association with time of onset and diabetic state. Int. J. Immunopathol. Pharmacol. 2006, 19, 639-646. [CrossRef] [PubMed]

299. Tuttolomondo, A.; Di Raimondo, D.; Pecoraro, R.; Maida, C.; Arnao, V.; Della Corte, V.; Simonetta, I.; Corpora, F.; Di Bona, D.; Maugeri, R.; et al. Early high-dosage atorvastatin treatment improved serum immune-inflammatory markers and functional outcome in acute ischemic strokes classified as large artery atherosclerotic stroke: A randomized trial. Medicine 2016, 95, e3186. [CrossRef]

300. Choi, J.C.; Lee, J.S.; Park, T.H.; Cho, Y.-J.; Park, J.-M.; Kang, K.; Lee, K.B.; Lee, S.-J.; Ko, Y.; Lee, J.; et al. Effect of pre-stroke statin use on stroke severity and early functional recovery: A retrospective cohort study. BMC Neurol. 2015, 15, 120. [CrossRef]

301. Jurcau, A.; Simion, A. Cognition, statins, and cholesterol in elderly ischemic stroke patients: A neurologist's perspective. Medician 2021, 57, 616. [CrossRef] 
302. Zhang, L.; Yang, L. Anti-inflammatory effects of vinpocetine in atherosclerosis and ischemic stroke: A review of the literature. Molecules 2014, 20, 335-347. [CrossRef]

303. Zhang, Y.; Li, J.; Yan, C. An update on Vinpocetine: New discoveries and clinical implications. Eur. J. Pharmacol. 2018, 819, 30-34. [CrossRef]

304. Spaccapelo, L.; Bitto, A.; Galantucci, M.; Ottani, A.; Irrera, N.; Minutoli, L.; Altavilla, D.; Novellino, E.; Grieco, P.; Zaffe, D.; et al. Melanocortin $\mathrm{MC}(4)$ receptor agonists counteract late inflammatory and apoptotic responses and improve neuronal functionality after cerebral ischemia. Eur. J. Pharmacol. 2011, 670, 479-486. [CrossRef] [PubMed]

305. Zendedel, A.; Habib, P.; Dang, J.; Lammerding, L.; Hoffmann, S.; Beyer, C.; Slowik, A. Omega-3 polyunsaturated fatty acids ameliorate neuroinflammation and mitigate ischemic stroke damage through interactions with astrocytes and microglia. J. Neuroimmunol. 2015, 278, 200-211. [CrossRef] [PubMed]

306. Yang, C.; Yang, Y.; DeMars, K.M.; Rosenberg, G.A.; Candelario-Jalil, E. Genetic deletion or pharmacological inhibition of cyclooxygenase-2 reduces blood-brain barrier damage in experimental ischemic stroke. Front. Neurol. 2020, 11, 887. [CrossRef]

307. Sasaki, T.; Kitagawa, K.; Sugiura, S.; Omura-Matsuoka, E.; Tanaka, S.; Yagita, Y.; Okano, H.; Matsumoto, M.; Hori, M. Implication of cyclooxygenase-2 on enhanced proliferation of neural progenitor cells in the adult mouse hippocampus after ischemia. J. Neurosci. Res. 2003, 72, 461-471. [CrossRef] [PubMed]

308. Schmidt, M.; Horváth-Puhó, E.; Christiansen, C.F.; Petersen, K.L.; Bøtker, H.E.; Sørensen, H.T. Preadmission use of nonaspirin nonsteroidal anti-inflammatory drugs and 30-day stroke mortality. Neurology 2014, 83, 2013-2022. [CrossRef]

309. Lin, S.-Y.; Wang, Y.-Y.; Chang, C.-Y.; Wu, C.-C.; Chen, W.-Y.; Liao, S.-L.; Chen, C.-J. TNF- $\alpha$ receptor inhibitor alleviates metabolic and inflammatory changes in a rat model of ischemic stroke. Antioxidants 2021, 10, 851. [CrossRef] [PubMed]

310. Lewis, B.P.; Burge, C.B.; Bartel, D.P. Conserved seed pairing, often flanked by adenosines, indicates that thousands of human genes are microRNA targets. Cell 2005, 120, 15-20. [CrossRef]

311. Liu, X.; Feng, Z.; Du, L.; Huang, Y.; Ge, J.; Deng, Y.; Mei, Z. The potential role of microRNA-124 in cerebral ischemia injury. Int. J. Mol. Sci. 2020, 21, 120. [CrossRef] [PubMed]

312. Volny, O.; Kasickova, L.; Coufalova, D.; Cimflova, P.; Novak, J. MicroRNAs in cerebrovascular disease. Adv. Exp. Med. Biol. 2015, 888, 155-195.

313. Hamzei, T.S.; Kho, W.; Aswendt, M.; Collmann, F.M.; Green, C.; Adamczak, J.; Tennstaedt, A.; Hoehn, M. Dynamic modulation of microglia/macrophage polarization by miR-124 after focal cerebral ischemia. J. Neuroimmune Pharmacol. 2016, 11, 733-748. [CrossRef] [PubMed]

314. Morel, L.; Regan, M.; Higashimori, H.; Ng, S.K.; Esau, C.; Vidensky, S.; Rothstein, J.; Yang, Y. Neuronal exosomal miRNAdependent translational regulation of astroglial glutamate transporter GLT1. J. Biol. Chem. 2013, 288, 7105-7116. [CrossRef] [PubMed]

315. Saraiva, C.; Talhada, D.; Rai, A.; Ferreira, R.; Ferreira, L.; Bernardino, L.; Ruscher, K. MicroRNA-124-loaded nanoparticles increase survival and neuronal differentiation of neural stem cells in vitro but do not contribute to stroke outcome in vivo. PLoS ONE 2018, 13, e0193609. [CrossRef]

316. Liu, X.S.; Chopp, M.; Zhang, R.L.; Tao, T.; Wang, X.L.; Kassis, H.; Hozeska-Solgot, A.; Zhang, L.; Chen, C.; Zhang, Z.G. MicroRNA profiling in subventricular zone after stroke: MiR-124a regulates proliferation of neural progenitor cells through Notch signaling pathway. PLoS ONE 2011, 6, e23461. [CrossRef]

317. Orset, C.; Haelewyn, B.; Allan, S.M.; Ansar, S.; Campos, F.; Cho, T.H.; Durand, A.; El Amki, M.; Fatar, M.; Garcia-Yébenes, I.; et al. Efficacy of alteplase in a mouse model of acute ischemic stroke: A retrospective pooled analysis. Stroke 2016, 47, 1312-1318. [CrossRef]

318. Dabrowska, S.; Andrzejewska, A.; Lukomska, B.; Janowski, M. Neuroinflammation as a target for treatment of stroke using mesenchymal stem cells and extracellular vesicles. J. Neuroinflamm. 2019, 16, 178. [CrossRef]

319. Zhang, L.; Yi, L.; Chopp, M.; Kramer, B.C.; Romanko, M.; Gosiewska, A.; Hong, K. Intravenous administration of human umbilical tissue-derived cells improves neurological function in aged rats after embolic stroke. Cell Transplant. 2013, 22, 1569-1576. [CrossRef]

320. Guzman, R.; Janowski, M.; Walczak, P. Intra-arterial delivery of cell therapies for stroke. Stroke 2018, 49, 1075-1082. [CrossRef] [PubMed]

321. Zhao, L.-R.; Duan, W.-M.; Reyes, M.; Keene, C.D.; Verfaillie, C.M.; Low, W.C. Human bone marrow stem cells exhibit neural phenotypes and ameliorate neurological deficits after grafting into the ischemic brain of rats. Exp. Neurol. 2002, 174, 11-20. [CrossRef]

322. Yoo, S.-W.; Chang, D.-Y.; Lee, H.-S.; Kim, G.-H.; Park, J.-S.; Ryu, B.-Y.; Joe, E.-H.; Lee, Y.-D.; Kim, S.-S.; Suh-Kim, H. Immune following suppression mesenchymal stem cell transplantation in the ischemic brain is mediated by TGF- $\beta$. Neurobiol. Dis. 2013, 58, 249-257. [CrossRef] [PubMed]

323. Karlupia, N.; Manley, N.C.; Prasad, K.; Schafer, R.; Steinberg, G.K. Intraarterial transplantation of human umbilical cord mononuclear cells is more efficacious and safer compared with umbilical cord mesenchymal stromal cells in a rodent stroke model. Stem Cell Res. Ther. 2014, 5, 45. [CrossRef] [PubMed]

324. Chen, J.; Chopp, M. Exosome therapy for stroke. Stroke 2018, 49, 1083-1090. [CrossRef] 
325. Liu, F.; McCullogh, L.D. Middle cerebral artery occlusion model in rodents: Methods and potential pitfalls. J. Biomed. Biotechnol. 2011, 2011, 464701. [CrossRef] [PubMed]

326. Hug, A.; Dalpke, A.; Wieczorek, N.; Giese, T.; Lorenz, A.; Auffarth, G.; Liesz, A.; Veltkamp, R. Infarct volume is a major determiner of post-stroke immune cell function and susceptibility to infection. Stroke 2009, 40, 3226-3232. [CrossRef] [PubMed] 